\title{
A PROTEÇÃO E A INCLUSÃO dA PESSOA HUMANA TRABALHADOR E DO TRABALHO NO BRASIL REPÚBLICA: FLUXOS E REFLUXOS
}

\section{THE PROTECTION AND INCLUSION OF WORKERS AND LABOR IN BRAZILIAN REPUBLIC: ADVANCES AND SETBACKS}

\section{MAURICIO GODINHO DELGADO}

Professor Titular do Centro Universitário do Distrito Federal (UDF) e de seu Mestrado em Direito das Relações Sociais e Trabalhistas e respectivo Grupo de Pesquisa "Constitucionalismo, Direito do Trabalho e Processo". Doutor em Filosofia do Direito (UFMG) e Mestre em Ciência Política (UFMG). Magistrado do Trabalho desde 1989, sendo Ministro do Tribunal Superior do Trabalho (TST) desde 2007. Autor de livros e artigos acadêmicos em sua área temática de pesquisa.

\section{GABRIELA NEVES DELGADO}

Professora Associada da Faculdade de Direito da UnB e de seu Doutorado e Mestrado em Direito, a par de Líder do Grupo de Pesquisa "Trabalho, Constituição e Cidadania" da mesma Universidade. Pós-Doutora em Sociologia do Trabalho pela UNICAMP. Doutora em Filosofia do Direito (UFMG) e Mestre em Direito do Trabalho (PUC Minas). Advogada. Autora de livros e artigos acadêmicos em sua área temática de pesquisa.

\section{RESUMO}

Objetivos: Este artigo objetiva analisar a dinâmica institucional e jurídica de proteção e inclusão da pessoa humana trabalhadora e do próprio trabalho na ordem jurídica da República do Brasil, com enfoque central nas inovações e aperfeiçoamentos propiciados pela Constituição Federal de 1988 no sistema trabalhista brasileiro oriundo das décadas de 1930 e 1940, nos distintos planos 
trabalhistas (Direito Individual, Direito Coletivo e Direito Processual do Trabalho) e o subsequente período de refluxo iniciado em 2016.

Metodologia: A metodologia deste estudo é dedutiva, associada a técnicas de pesquisa bibliográfica, por meio da revisão de doutrina, periódicos, artigos científicos e legislação. $\mathrm{O}$ estudo foi estrategicamente dividido em uma pesquisa detalhada de temas que se relacionam estreitamente com o Direito do Trabalho.

Resultados: Como resultado da pesquisa, conclui-se que, a partir de 2016 iniciouse um período de intenso e generalizado refluxo no padrão de proteção e inclusão da pessoa humana trabalhadora e do trabalho no Direito brasileiro; e esse intenso refluxo atingiu, fortemente, todos os planos da seara trabalhista, o Direito Individual, o Direito Coletivo e o Direito Processual do Trabalho. A lógica e o direcionamento desse refluxo podem, em certa medida, ser enquadrados como parte das dinâmicas disruptivas verificadas, nas últimas décadas, na seara socioeconômica das relações trabalhistas. No plano do Direito Individual do Trabalho, a Lei $n \cong$. 13.467/2017 rebaixou, substancialmente, o patamar civilizatório mínimo justrabalhista até então vigente no País. Vários direitos trabalhistas tiveram sua abrangência profundamente reduzida, quer mediante a restrição do próprio conceito do respectivo direito, quer mediante a restrição de sua área de incidência. Outros direitos foram simplesmente extintos e novos institutos e procedimentos foram criados, com o sentido de restrição de direitos e garantias jurídicas.

Contribuições: As referências aos momentos e situações de fluxos e refluxos na linha jurídica de proteção e inclusão da pessoa humana trabalhadora e do trabalho no Brasil República.

PALAVRAS-CHAVE: Direito do Trabalho; inclusão; Constituição de 1988; Refluxos trabalhistas de 2016.

\section{ABSTRACT}

Objectives: to point out the technological advances registered in the Brazilian Judiciary System in the digital age, mainly the benefits that the engineering has provided in the improvement of artificial intelligence tools which reflect in the speed of judgments, as well as defining the limits of the use of such resources in view of the of the peculiarities of the judging activity in an immersive and sometimes exclusive demand, in the dynamics between texts and contexts.

Methodology: The methodology of this study is deductive coupled with techniques of bibliographical research by way of reviewing doctrine, journals, scientific articles and legislation. The study was strategically divided into a detailed investigation of themes that closely relate to the Labor Law.

Results: As a result of the research, it is concluded that, starting in 2016, a period of intense and generalized reflux in the pattern of protection and inclusion of the human 
worker and labor in Brazilian law began; and this intense reflux affected, strongly, all the plans of the labor field, Individual Law, Collective Law and Procedural Labor Law. The logic and direction of this reflux can, to a certain extent, be framed as part of the disruptive dynamics verified in the last decades in the socioeconomic field of labor relations. In terms of Individual Labor Law, Law no. 13,467/2017 substantially lowered the minimum level of civilization in Brazil until then in force. Several labor rights had a profoundly reduced scope, either by restricting the concept of the respective right or by restricting its area of incidence. Other rights were simply extinguished and new institutes and procedures were created, with the sense of restricting rights and legal guarantees.

Contributions: The discussion of working together between lawyers in the rational implementation of digital tools at their disposal and software engineers to simplify the legal world, through the development of intelligent systems, with the aim of understanding and applying their knowledge in the best way to solving questions about the administrative and technical complexity of the legal system, adequately responding to the demands of society.

KEYWORDS: Labor Law; inclusion; Constitution of 1988; labor reflux of 2016.

\section{INTRODUÇÃO}

O presente artigo acadêmico objetiva analisar a dinâmica institucional e jurídica de proteção e inclusão da pessoa humana trabalhadora e do próprio trabalho na ordem jurídica da República do Brasil. O seu enfoque central situa-se nas mudanças e avanços propiciados pela Constituição Federal de 1988 no sistema trabalhista brasileiro oriundo das décadas de 1930 e 1940, que culminou com a aprovação da Consolidação das Leis do Trabalho, em 1943.

É parte do enfoque central do artigo também examinar o período de refluxo nas garantias e proteções trabalhistas iniciado no ano de 2016, que culminou embora sem ainda encerrar o seu ciclo disruptivo - com a Lei n. 13.467/2017, que aprovou a denominada reforma trabalhista na ordem jurídica e instituições laborais no País.

Em sua análise, o texto acadêmico pretende apontar os momentos e situações de fluxos e refluxos na linha jurídica de proteção e inclusão da pessoa humana trabalhadora e do trabalho no Brasil República. 
Para atingir os seus objetivos, o estudo perpassa - ainda que sumariamente - por momentos históricos distintos da temática trabalhista na era republicana brasileira. Nesse quadro, inicia-se com um olhar sobre as peculiaridades do período conhecido como "Primeira República", que se estende de 1889 até 1930. Nessa fase, mostrou-se parca e rarefeita a institucionalidade trabalhista no País, sem a presença de uma complexidade de diplomas legais configuradores de um todo diversificado, orgânico e sistemático apto a configurar, efetivamente, um segmento jurídico plenamente estruturado. Se não bastasse, tal fase igualmente não ficou conhecida por ostentar um movimento sindical robusto, diversificado e poderoso o bastante para estruturar um sistema de normatização jurídica no plano das negociações coletivas trabalhistas com o empresariado brasileiro - o qual, de resto, também se mostrava rarefeito nessa época.

O segundo momento histórico de destaque é composto pelos anos de 1930 até 1943 (data de aprovação da Consolidação das Leis do Trabalho) ou até 1945 (data da queda do Governo Vargas, que fora iniciado com a Revolução de 1930). Nessa fase é que se constrói grande parte das instituições e do campo jurídico trabalhista, em seus distintos segmentos, particularmente o Direito Individual do Trabalho, o Direito Coletivo do Trabalho e o Direito Processual do Trabalho. $O$ artigo acadêmico, a propósito, procurará aferir se essa importante era constituiu-se preponderantemente em um fluxo de proteção e inclusão ou, ao inverso, em um período desigualitário, tal como a fase imediatamente anterior.

O sistema trabalhista arquitetado e desenvolvido neste 13/15 anos, desde a Revolução de 30, de toda maneira, manter-se-ia firme por cerca de cinco décadas, passando pela República Democrático-Desenvolvimentista (1945-1964) e pelo regime civil-militar autoritário (1964-1985). Essa circunstância será bem destacada no presente estudo, que procurará indicar, ainda, os aspectos de fluxos e refluxos que permeiam tal período.

Cumprido esse escorço histórico-jurídico, o texto acadêmico abordará a importante era deflagrada pela Constituição da República Federativa do Brasil, promulgada em outubro de 1988. Uma vez mais, procurará indicar os aspectos jurídicos e institucionais que traduzem um fluxo de proteção e inclusão civilizatórias, 
sem descurar do exame de situações ou aspectos que possam apontar na direção inversa.

Por fim, o presente artigo analisará a fase iniciada no ano de 2016, tomando como parâmetro um seu momento e realização específicos, consubstanciados na reforma trabalhista implementada pela Lei n. 13.467, de 13.7.2017, que entrou em vigor em 11 de novembro do mesmo ano. Mais uma vez, o estudo acadêmico buscará expor os aspectos jurídicos e institucionais afetados pela reforma que importam à dualidade fluxos e refluxos de proteção e inclusão da pessoa humana trabalhadora e do trabalho no Brasil República.

\section{TEMPO, ESPAÇO E DIREITO DO TRABALHO: FRAGMENTOS DA MEMÓRIA DO BRASIL REPÚBLICA PARA SE COMPREENDER O TEMPO PRESENTE}

As visões temporais e espaciais pretéritas e seguintes são decisivas para a mais ampla e abrangente compreensão da contemporaneidade e de seus fenômenos humanos e sociais. Afinal, tempo e espaço são "domínios universais e transculturais da linguagem e do pensamento humano" (SINHA; BERNÀRDEZ, 2015, p.54). São, ainda, elementos constitutivos da identidade humana.

A linguagem do tempo é comumente identificada por "mapeamentos metafóricos", especialmente para reforçar seu dinamismo histórico, mediado por "padrões e processos culturais", em passagens tipificadas por fluxos e refluxos (SINHA; BERNÀRDEZ, 2015, p.53).

O tempo da vida, em sua estruturação sociocultural, deve ser compreendido na dimensão de mudança (ARNHEIM, 1962), com seus fluxos e refluxos, suas acelerações e regressões, suas pausas e pulsões.

O Direito do Trabalho reflete este dinamismo temporal, com fases de fluxos e refluxos em seu sistema jurídico de proteção ao trabalho humano.

Neste artigo, pretende-se apresentar alguns fragmentos da memória do Direito do Trabalho, para, em seguida, estruturar alguns pressupostos reflexivos para a contemporaneidade do Direito do Trabalho no Brasil. As análises críticas e propositivas aqui expostas serão especialmente direcionadas ao tempo presente, 
considerada a vigência da Lei 13.467/2017 - a denominada "Lei da Reforma Trabalhista".

Este resgate histórico, somado à construção de bases propositivas para 0 futuro das relações de trabalho e de emprego no País, é que irá permitir pensar quais são e quais devem ser as telas de proteção social no Brasil hoje, sobretudo após a aprovação da reforma trabalhista pela Lei n. 13.467, de 2017.

Pensar como o Direito do Trabalho pode preservar seu compromisso de atuação como instrumento civilizatório, ao invés de mecanismo de exclusão e discriminação. Assim, questiona-se: que Direito do Trabalho será possível reconstruir?

Para compreender os impactos da reforma trabalhista considera-se fundamental rememorar, mesmo que brevemente, a regulação social do trabalho no Brasil, porque toda interpretação de norma jurídica é texto e contexto.

É necessário, portanto, analisar a historicidade das normas jurídicas trabalhistas.

No Brasil, o processo normativo trabalhista foi marcado por distintos períodos de regulação social: o período de manifestações incipientes e esparsas, entre 1889 e 1930, em que o Direito do Trabalho, como complexo normativo, efetivamente ainda não se estruturara; o período de institucionalização do Direito do Trabalho, deflagrado, inicialmente, entre 1930 a 1945 (ou 1943, considerada a aprovação da CLT) e, logo em seguida, expandido e generalizado no País até o final dos anos 1980; o período paradigmático aberto pela Constituição Federal de 1988, que propiciou, em 27 anos de vigência constitucional, até 2015, a renovação democrática do Direito do Trabalho no Brasil; por fim, o período começado em 2016, que se caracteriza pelos profundos refluxos na proteção à pessoa humana trabalhadora e ao trabalho no Direito brasileiro. 


\section{MANIFESTAÇÕES INCIPIENTES E ESPARSAS DO DIREITO DO TRABALHO NO PERÍODO HISTÓRICO REPUBLICANO BRASILEIRO INICIAL}

A institucionalização do Direito do Trabalho no Brasil ocorreu tardiamente, apenas no período republicano deflagrado com a Revolução de 30 - movimento político e militar que reverteu, no País, a hegemonia política e ideológica do segmento agroexportador de café, que comandava a Primeira República desde a derrubada da Monarquia no final do século XIX.

No período republicano inicial (e, é claro, também no período monárquico antecedente), até a Revolução de 1930, a economia brasileira era essencialmente agrícola. A partir de finais do século XIX é que começaram a despontar pequenos nichos industrializantes em certas regiões do País, com ênfase, especialmente, em São Paulo, mas sem a aptidão de melindrar a plena hegemonia do segmento rural na economia do País. Ora, sem a presença de uma política industrializante estatal ao longo de mais de um século desde a Independência, ocorrida em 1822 - salvo raros e curtos momentos em mais de cem anos -, o fato é que a economia brasileira não desenvolveu um parque industrial pujante e diversificado até então em sua História. ${ }^{1}$

Se não bastasse, os governos da denominada "República Velha" (18891930) não evidenciavam qualquer interesse e sensibilidade pela "questão social" salvo raríssimos instantes legislativos -, não produzindo legislação trabalhista intensa e diversificada nesse período.

Dois fatos (ou omissões) bem expressam essa fase: de um lado, apenas em 1926, já nas proximidades do término desse período político e institucional de cerca de quatro décadas, é que, por emenda constitucional, se realizou a inserção, na Constituição de 1891, de regra concernente à competência da União para legislar sobre o Direito do Trabalho. De outro lado, embora o País tenha participado da Conferência de Versalhes, em 1919, e do processo de criação da Organização

\footnotetext{
${ }^{1}$ Sobre esse período histórico republicano pré-1930 e as vicissitudes do campo social, econômico e institucional que importa ao Direito do Trabalho, consultar, por exemplo, os seguintes autores e obras: DELGADO, 2016, p. 61-73 (paginação da versão impressa do periódico; há também versão digital, online, da revista); DELGADO, 2018, p. 124-127; FAUSTO, 1976; MORAES FILHO, 1960, p. 312314; VIANNA, 1989, p. 45-46.
} 
Internacional do Trabalho, no mesmo ano, não ratificou, na Primeira República, nenhuma das 30 Convenções Internacionais do Trabalho aprovadas pela OIT entre 1919 e 1930.

Nesse contexto eminentemente rural e bastante excludente, acompanhado de forte repressão estatal contra as organizações e movimentos dos trabalhadores, o sindicalismo obreiro também não conseguiu alcançar, na época, elevada densidade e força em sua organização, não conseguindo provocar o surgimento, na sociedade civil, de uma dinâmica sólida e contínua de negociação coletiva trabalhista, com a geração de razoável diversidade de documentos coletivos negociados que, em seu conjunto, fossem aptos a deflagrar a criação de um Direito do Trabalho do tipo extraestatal.

No campo da legislação estatal, é evidente que determinados diplomas legais surgiram nessa fase, mas sem conseguirem instituir, em seu conjunto, um campo normativo amplo, diversificado e complexo, capaz de já ser identificado como um efetivo Direito do Trabalho (este compreendido, logicamente, como um complexo de princípios, institutos e regras jurídicas reguladoras da relação de emprego e de relações socioeconômicas correlatas). Aliás, boa parte desses diplomas normativos era de origem estadual - ao invés de federal -, provinda especialmente do Estado de São Paulo, onde o movimento sindical era mais bem estruturado em certos setores socioeconômicos, tais como os portos marítimos (Santos, em especial), as estradas ferroviárias e o segmento bancário.

Por essa razão é que Mauricio Godinho Delgado denomina essa fase do Direito do Trabalho brasileiro como de "manifestações incipientes e esparsas". ${ }^{2}$

2 DELGADO, 2017, p. 115-118. O autor situa a fase de manifestações incipientes e esparsas a partir de 1888, pela circunstância de a Lei Áurea, com a libertação dos escravos, ter demarcado, implicitamente, uma nova e larga seara para a afirmação da relação empregatícia no sistema socioeconômico brasileiro (seara que não resultou, lamentavelmente, nem em uma legislação inclusiva para os escravos recém libertados, nem em uma legislação trabalhista inclusiva para os trabalhadores empregados no sistema socioeconômico da época). O autor estende tal período até a Revolução de Outubro de 1930, ou seja, de 1988 a 1930. 


\section{INSTITUCIONALIZAÇÃO DO DIREITO DO TRABALHO NO BRASIL, NO SÉCULO XX, A PARTIR DA REVOLUÇÃO DE 1930}

Um campo normativo se institucionaliza, adquirindo autonomia científica e institucional, quando se torna, realmente, um complexo diversificado, sistemático e diferenciado de princípios, institutos e regras jurídicas reguladoras de determinadas relações humanas e/ou sociais específicas.

No caso do Direito do Trabalho, isso acontece quando passa a existir, na respectiva sociedade política e na sociedade civil, um complexo de princípios, institutos e regras jurídicas reguladoras da relação de emprego e de relações socioeconômicas correlatas ou equiparáveis. E esse fato somente aconteceu a partir das mudanças ocorridas no Brasil com a derrubada da hegemonia política, institucional, econômica, social e cultural do segmento agroexportador, pela Revolução de Outubro de 1930, com as mudanças de políticas públicas imediatamente deflagradas desde então, as quais tiveram resultados importantes em diversos campos do Direito, em particular no campo jurídico trabalhista.

A institucionalização do Direito do Trabalho no Brasil aconteceu durante os 15 anos do Governo Vargas, no contexto das inúmeras modificações promovidas no País pela nova Administração Federal. Nessa fase, o ápice desse processo de institucionalização verificou-se com a publicação, em 1943, da Consolidação das Leis do Trabalho (CLT), sistematizando os inúmeros diplomas normativos e regras jurídicas editados desde 1930 no plano federal, com o acréscimo de algumas inovações introduzidas pelo diploma legal consolidado.

A partir dessa fase, pode-se falar, de fato, na presença de um campo sistematizado do Direito Individual do Trabalho, do Direito Coletivo do Trabalho (nesta esfera, com restrições, conforme se verá) e do Direito Processual do Trabalho na ordem jurídica brasileira.

Esse período de década e meia de intensa atividade legiferante na seara trabalhista tem de ser compreendido de maneira ampla e conjugada, como parte de um processo complexo e contraditório. De um lado, uma espécie de revolução burguesa passiva vivenciada pelo País, estimulada pelas políticas públicas estatais em favor da franca industrialização; de outro lado, uma inovadora dinâmica de 
inclusão socioeconômica no interior de uma economia e de uma sociedade extremamente excludentes desde todo o período histórico anterior; se não bastasse, uma também inovadora dinâmica de alargamento da cidadania no plano da sociedade civil e da sociedade política, relativamente aos setores sociais não dominantes, que jamais gozaram dessa cidadania nas décadas precedentes. Entretanto, tudo isso, contraditoriamente, foi estruturado e vivido em certo momento histórico profundamente autoritário da vida política do País (em particular, o período do Estado Novo, de novembro de 1937 até 1945).

Sobre esse processo complexo e multifacetado mais amplo, assim se expressa Mauricio Godinho Delgado:

Sinteticamente, o sistema trabalhista brasileiro arquitetado entre 1930 e 1943 foi resultado de distintos fatores convergentes: a) política industrializante e de urbanização promovida firmemente pelo Governo Vargas, da qual a política trabalhista era uma das dimensões mais significativas; b) a necessidade de inclusão econômica de importante setor da população do País, os trabalhadores urbanos inclusão que fora, nas décadas precedentes, bastante negligenciada, senão denegada inteiramente; c) a conveniência, para os novos governantes, de se proceder à inclusão política desse mesmo setor populacional no sistema institucional de poder, como mecanismo para atenuar o poder político-institucional antes incontrastável da oligarquia agroexportadora de café no sistema socioeconômico e político brasileiro, até então fielmente acompanhada por seus aliados políticos tradicionais; d) a incorporação, pelo imaginário das forças políticas vitoriosas na Revolução de 30 , das críticas à política trabalhista excludente da República Velha, a qual tendia a considerar a questão social como uma simples "questão de Polícia" frase atribuída, aliás, ao Presidente Washington Luís. Nessa incorporação, o novo governo buscou internalizar, rapidamente, no Direito do País, boa parte das normas editadas pela Organização Internacional do Trabalho, entidade multilateral instituída em 1919 pelo Tratado de Versalhes e que, até 1930, já havia aprovado cerca de 30 Convenções Internacionais do Trabalho, acompanhadas do mesmo número aproximado de Recomendações Internacionais da OIT. ${ }^{3}$

3 DELGADO, 2019 (no prelo). Acrescente-se que a OIT, até 1939 - portanto muito antes da elaboração e publicação da CLT, de 1943 -, já havia aprovado cerca de 60 Convenções 
No Brasil, portanto, o período de institucionalização do Direito do Trabalho teve na CLT, de 1943, seu principal marco legislativo, uma vez que esse diploma legal sistematizou os inúmeros diplomas normativos publicados a contar de outubro de 1930. Assim, de fato, a Consolidação das Leis do Trabalho assumiu papel decisivo para a construção e progresso do trabalho regulado no País, sobretudo se considerada a precariedade da realidade normativa trabalhista brasileira existente até a década de 1930.

A CLT também assumiu papel definitivo a favor da institucionalização de um modelo de contratação trabalhista próprio (o contrato de trabalho, com a formalização do vínculo de emprego mediante assinatura da CTPS), caracterizado por importante isonomia material, afastando-se do individualismo e do formalismo típicos das contratações civilistas clássicas ${ }^{4}$.

Seu paradoxo, contudo, reside no fato de ter sido gestada em período autoritário da vida político-institucional brasileira, dentro do cenário autocrático imposto pela Constituição de 1937. Este "pecado original" da Consolidação das Leis do Trabalho - a circunstância de ter sido aprovada em fase ditatorial do País - é assim examinado por Mauricio Godinho Delgado e Gabriela Neves Delgado (2008, p.19):

[...] a circunstância de se ter gestado em período autocrático da vida político-institucional brasileira, em 1943, embora inegavelmente grave, não macula toda a obra jurídica, econômica e cultural inserida no diploma normativo. Mostra-se comprometedor essencialmente quanto à sua concepção de Direito Coletivo do Trabalho, em especial no tocante à estrutura corporativista do sindicalismo brasileiro, que desponta como pouco funcional para fazer frente aos desafios democráticos apresentados pela evolução histórica do País a partir de fins do regime autoritário de $1964 / 1985$.

Em contrapartida ao seu "pecado original" (que afetou, principalmente, o Direito Coletivo do Trabalho, com a estrutura sindical corporativista), são inúmeros os méritos da Consolidação das Leis do Trabalho e do Direito do Trabalho institucionalizado a partir daquele período no País. Citem-se, ilustrativamente, ainda

Internacionais do Trabalho e cerca de 60 Recomendações Internacionais, documentos que, certamente, tiveram enorme influência na construção do Direito do Trabalho e da CLT no Brasil.

${ }^{4}$ Sobre o tema, consultar também: TEPEDINO; MELLO FILHO; FRAZÃO; DELGADO, 2013. 
que de maneira sintética: uma legislação econômico-profissional que estabelece um patamar mínimo de contratação e gestão trabalhistas na economia brasileira, apto a assegurar, por meio de princípios e regras imperativas, um razoável nível de inclusão e proteção da classe trabalhadora no sistema socioeconômico capitalista em desenvolvimento no País; um sistema processual trabalhista, com um segmento próprio da tecnocracia estatal especializado na solução das lides laborais, caracterizado pela Justiça do Trabalho (a qual, a partir da Constituição de 1946, seria integrada ao conjunto do Poder Judiciário); um sistema sindical que, com todos os seus problemas e limitações, teve também o papel de elevar, ao longo das décadas seguintes, o patamar mínimo de contratação e gestão trabalhistas próprios à economia brasileira.

Ressalve-se que, em decorrência do pacto político complexo de sustentação do novo governo instalado em outubro de 1930, a nova legislação trabalhista não foi estendida ao campo brasileiro (onde, nessa fase, residia a maioria da população do País), nem foi estendida à enorme categoria dos trabalhadores domésticos. Mesmo com essas duas graves omissões iniciais (que seriam supridas tempos depois), não se pode diminuir a importância, desde essa época, do Direito do Trabalho e do novo sistema trabalhista como exemplos pioneiros do surgimento de um até então inusitado fluxo de proteção e inclusão jurídicas e institucionais à pessoa humana trabalhadora e ao trabalho na História do Brasil.

\section{CONTINUIDADE E EXPANSÃO, APÓS 1945, DO DIREITO DO TRABALHO INSTITUCIONALIZADO NO BRASIL}

A fase de institucionalização do Direito do Trabalho no Brasil continua após a derrubada do Governo Vargas, em 1945, estendendo-se até o advento da Constituição de 1988 - momento em que, realmente, mudanças muito importantes foram deflagradas no Direito do Trabalho brasileiro.

Essa continuidade da fase de institucionalização da seara jurídica trabalhista no País, após 1945, passou por dois períodos distintos: o da República Democrático- 
Desenvolvimentista, entre 1945 e 1964, e o do Regime Autoritário Militar-Civil, entre 1964 e 1985.

No período da República Democrático-Desenvolvimentista (1945-1964), o Direito do Trabalho se expandiu bastante, afirmando-se crescentemente na economia e na sociedade brasileiras.

Essa expansão se fez notar com maior clareza no segmento do Direito Individual do Trabalho, em que vários diplomas legais novos surgiram, de maneira geral no sentido de elevar o patamar civilizatório mínimo instituído nos 15 anos precedentes a 1945. Citem-se nesse grupo diversas leis regulando o exercício de profissões e o respectivo contrato de emprego: por exemplo, a Lei n. 3.207/1957, regulamentadora do contrato de trabalho dos empregados vendedores-viajantes ou pracistas; a Lei n. 3.270/1957, que fixa jornada especial para os cabineiros de elevador; a Lei n. 3.999/1961, que regula o salário mínimo dos médicos e cirurgiõesdentistas.

Citem-se também nesse grupo novos diplomas legais aperfeiçoando a regulação de direitos trabalhistas mencionados laconicamente pelo texto original da CLT ou, até mesmo, instituindo direitos trabalhistas novos: por exemplo, a Lei n. $605 / 1949$, reguladora do descanso semanal remunerado e do descanso remunerado em feriados; a Lei n. 4.090/1962, instituidora do $13^{\circ}$ salário.

Por fim, também nesse grupo, deve ser enfatizada a impactante Lei $\mathrm{n}$. 4.214/1963, denominada Estatuto do Trabalhador Rural, que estendeu a legislação trabalhista ao campo brasileiro. Esse diploma normativo supriu, conforme se percebe, a censurável omissão existente no patamar jurídico trabalhista aprovado entre 1930-1945.

No segmento do Direito Coletivo do Trabalho não despontaram inovações legais significativas, desenvolvendo-se o período democrático de 1945 até abril de 1964 como uma fase de sedimentação e generalização na economia e na sociedade do sistema sindical institucionalizado no período imediatamente anterior.

No segmento do Direito Processual do Trabalho, os 20 anos situados entre 1945 e 1964 foram também de sedimentação do sistema judicial e processual trabalhista criado no Governo Vargas. A Constituição de 1946, nesse aspecto como adiantado -, aperfeiçoou o sistema, ao integrar ao Poder Judiciário a Justiça 
do Trabalho, retirando-a do âmbito meramente administrativo em que fora originalmente inserida pelo Decreto-Lei n. 1.237/1939 (a instalação efetiva da estrutura nacional da Justiça do Trabalho aconteceu apenas em 1ํㅡ de maio de 1941, registre-se). Nas duas décadas seguintes a essa fase inicial, não houve ampliação no número de Tribunais Regionais do Trabalho, mantendo-se apenas os oito TRTs iniciais; porém, na base do sistema judicial trabalhista, houve um certo alargamento do número de Juntas de Conciliação e Julgamento (de 31 JCJs em 1945 para 137 JCJs em 1964), mas ainda sem a aptidão de generalizar, de fato, a base do sistema judicial especializado ao longo do território brasileiro. ${ }^{5}$

O período do regime autoritário militar-civil (1964-1985), por sua vez, deu continuidade à fase de institucionalização e expansão do Direito do Trabalho no País, embora com nítidos pontos de regressão na política pública trabalhista e nos segmentos normativos do Direito Individual do Trabalho e do Direito Coletivo do Trabalho. Manteve-se, sem dúvida, a tendência de institucionalização do Direito do Trabalho e de seus ramos conexos no Brasil, porém com algumas nítidas alterações regressivas em certos aspectos da seara trabalhista institucionalizada. Não há como se negar, nessa fase, portanto, a presença de um refluxo na dinâmica de conquista de direitos trabalhistas, a par de um refluxo no funcionamento do Direito Coletivo do Trabalho, especialmente em seu segmento vinculado ao sindicalismo.

No plano do Direito Individual do Trabalho, por exemplo, a legislação federal passou a restringir elevações reais de salários, até, pelo menos, 1968, sob o fundamento de assegurar higidez à política de combate à inflação adotada a partir de abril de $1964 .{ }^{6}$ Ao lado disso, buscou enfraquecer o sistema estabilitário no emprego e de indenização rescisória por tempo de serviço estruturado na CLT, mediante a criação, pela Lei n. 5.107/1966 (vigente desde janeiro de 1967), de um

\footnotetext{
${ }^{5}$ Sobre a evolução institucional da Justiça do Trabalho no Brasil, desde a sua criação em 1939, pelo Decreto-Lei n. 1.237/39, e sua efetiva instalação, em todo o País, no dia 1ำ de maio de 1941, até o período mais recente, consultar o seguinte estudo: DELGADO; DELGADO, 2017, p. 145-156. Os dados estatísticos sobre a criação de Juntas de Conciliação e Julgamento, nessa fase (e, posteriormente, a criação de novos TRTs), são fornecidos pelo Tribunal Superior do Trabalho (TST), por sua Coordenadoria de Estatística e Pesquisa (CEST).

6 São diplomas normativos dessa fase inicial de quatro anos de severa restrição a reajustes de salários: Decreto n. 53.936/1964; Decreto n. 54.018/64; Decreto n. 54.228/64; Lei n. 4.589/64; Lei n. 4.725/65; Decreto n. 57.271/65; Decreto-Lei n. 229/67 (que conferiu nova redação ao art. 623 da CLT). A respeito, DELGADO, 2018, p. 933.
} 
sistema alternativo ao celetista, construído em torno do Fundo de Garantia do Tempo de Serviço (FGTS). Em pouco tempo, a sistemática do FGTS tornou-se, na prática, imperante no mercado de trabalho, facilitando, largamente, a dispensa sem justa causa no mercado de trabalho do País.

Além disso, em 1974, a Lei n. 6.019 criou uma então inusitada figura contratual trabalhista - o contrato de trabalho temporário. Esta figura, mesmo sendo apenas provisória, estimulou a ideia e a prática da terceirização no mundo empresarial e do trabalho ao longo das décadas seguintes. Essa ideia e essa prática se tornariam, tempos depois, um irresistível instrumento precarizador das condições de trabalho na economia e sociedade brasileiras.

É necessário reconhecer, porém, que se manteve a inclusiva extensão do Direito do Trabalho ao campo brasileiro, por intermédio da Lei n. 5.889/1973, mesmo tendo este diploma revogado o anterior Estatuto do Trabalhador Rural (Lei $n$. 4.214/1963).

Por outro lado, nessa fase de autoritarismo, foram editados dois diplomas legais de caráter inclusivo na ordem jurídica trabalhista. O primeiro deles foi a Lei $n$. 5.859, de 1973, reguladora do contrato de trabalho doméstico - até então situado inteiramente fora de qualquer proteção trabalhista. Mas a proteção inclusiva trazida pela nova lei mostrava-se bastante modesta, pois abrangia apenas a assinatura da CTPS, com os recolhimentos mensais previdenciários pertinentes; a concessão de férias anuais remuneradas, à base de 20 dias úteis; e a inserção do(a) empregado(a) doméstico(a) no sistema geral de Previdência Social do País. O segundo desses diplomas legais inclusivos foi o referente aos atletas profissionais futebolistas: a Lei n. 6.354, de 1976.

No plano do Direito Coletivo do Trabalho, conforme dito, a marca dessa fase autoritária foi a profunda repressão direcionada ao sindicalismo no País, com a intervenção, pelo Ministério do Trabalho, em centenas de entidades sindicais, além do afastamento da vida sindical e da própria vida política - neste caso, por intermédio de cassações de direitos políticos - de diversas lideranças do sindicalismo brasileiro. É igualmente marca distintiva do período a ampla repressão sobre o direito de greve. 
Por outro lado, uma mudança previdenciária determinada em 1966 afetou, de certo modo, em parte, o modelo sindical preexistente. É que a unificação das autarquias previdenciárias autônomas oriundas das décadas de 1930/40 e anos seguintes (IAPM; IAPC; IAPB; IAPI etc), em um único órgão federal centralizado (o então denominado Instituto Nacional de Previdência Social - INPS -, criado pelo Decreto-Lei n. 72, 21.11.1966), fez extinguir a participação sindical nas direções dos Institutos de Aposentadorias e Pensões, eliminando, dessa maneira, esse traço corporativista do sistema sindical organizado desde os anos 1930/40. Essa mudança legal e institucional iria propiciar, a partir de então, a estruturação de um sistema de Seguridade Social eminentemente público e muito mais amplo e técnico no território brasileiro.

No plano do Direito Processual do Trabalho, finalmente, a fase de institucionalização do sistema trabalhista brasileiro recebeu significativo impulso, mediante a criação de quatro novos Tribunais Regionais do Trabalho ultrapassando-se, pois, o limite original de oito TRTs estruturados nos anos de 1940. Integra a mesma dinâmica de institucionalização o aumento do numero de Juntas de Conciliação e Julgamento no território brasileiro. De fato, o TRT da 9a Região, com sede em Curitiba, foi criado pela Lei n. 6.927/1981; o TRT da 10ª Região, com sede em Brasília, foi criado pela Lei n. 6.927/1981; o TRT da 11ª Região, com sede em Manaus, foi criado em 6.915/1981; e, por fim, o TRT da 12 ${ }^{\text {a }}$ Região, com sede em Florianópolis, foi criado pela Lei n. 6.928/1981. Ademais, de 1964 até o final de 1984, o número de JCJs passou de 137 para 382, com a criação de 245 novas unidades jurisdicionais em municípios. ${ }^{7}$

Ainda no plano do Direito Processual do Trabalho - embora com repercussões também no Direito Coletivo do Trabalho - surgiu a importante Lei n. 5.584, de 1972, estabelecendo regras distintivas para o Processo Trabalhista, a par de fixar preceitos para a atuação administrativa e judicial dos sindicatos de trabalhadores. ${ }^{8}$

\footnotetext{
${ }^{7}$ Conforme DELGADO; DELGADO, 2017, p. 145-156. Os dados estatísticos sobre a criação de TRTs e de Juntas de Conciliação e Julgamento, constantes do estudo ora referenciado, foram fornecidos pelo TST, por meio de sua Coordenadoria de Estatística e Pesquisa (CEST).

${ }^{8}$ Sobre a evolução histórica do sistema trabalhista celetista, consultar também DELGADO, Mauricio Godinho; DELGADO, 2008.
} 


\section{A CONSTITUIÇÃO DE 1988 E A RENOVAÇÃO DEMOCRÁTICA DO DIREITO DO TRABALHO NO BRASIL}

O final do regime autoritário militar-civil em 15 de março de 1985 conduziu ao início de nova era política e institucional no País, em que se convocou e se reuniu a Assembleia Nacional Constituinte (1987-1988), dando origem à nova Constituição da República Federativa do Brasil. Essa nova era abriu larga retomada a uma importante dinâmica histórica de proteção e inclusão normativas à pessoa humana trabalhadora e ao trabalho no Brasil República.

Historicamente, essa nova era deve ser dividida em dois períodos: o primeiro, da transição democrática, situado entre 15.3.1985 e 4.10.1988; e o segundo, inaugurado pela promulgação da nova Constituição Federal, ocorrida em cinco de outubro de 1988, estendendo-se por cerca de 27 anos de plenitude constitucional e democrática.

O primeiro período, na verdade, já iria se mostrar fortemente influenciado pelo espirito de democratização do País e de suas instituições, sendo, no campo trabalhista, um claro prenúncio dos avanços democráticos institucionalizados pela futura Constituição da República.

O segundo período, entre 1988 e 2015, caracterizou-se pelo desenvolvimento e maturação de enormes avanços democráticos e inclusivos no sistema trabalhista brasileiro, de maneira geral inspirados pela matriz constitucional aprovada 50 anos após a Revolução de 1930, ou seja, em cinco de outubro de 1988.

\subsection{A TRANSIÇÃO DEMOCRÁTICA DE 15 DE MARÇO DE 1985 ATÉ A CONSTITUIÇÃO DE 1988}

Nesse curto lapso de 3,5 anos, foram regulamentadas algumas atividades profissionais ou aspectos a elas inerentes. É o que aconteceu, por exemplo, com a incidência do adicional de periculosidade para os empregados do setor de energia elétrica (Lei $n$. 7.369, de 20.9.85) e com o exercício da profissão de técnico de radiologia (Lei n. 7.394, de 29.10.85).

No mesmo período foi criada nova e importante parcela trabalhista no plano 
do Direito Individual do Trabalho: o vale-transporte, instituído pelas Leis n. 7.418, de 16.12.1985, e n. 7.619/1987.

No plano do Direito Coletivo do Trabalho, foram cessadas, política e administrativamente, as intervenções estatais nas entidades do sindicalismo, em antecipação à incorporação dos princípios da liberdade sindical e da autonomia das entidades sindicais pela futura Constituição da República. Nesse quadro de efetivação prática desses dois princípios internacionais do Direito Sindical - mesmo antes da promulgação da nova Constituição -, três centrais sindicais foram estruturadas no País ao longo da década de 1980: a CUT, em 1983; a CGT, em 1986; e a CGTB, também em 1986. Após a Constituição de 1988, outras centrais sindicais foram instituídas. ${ }^{9}$

No plano do Direito Processual do Trabalho, a fase de institucionalização do sistema trabalhista brasileiro recebeu significativo impulso, mediante a criação de quatro novos Tribunais Regionais do Trabalho, de maneira a serem atingidos 16 TRTs em todo o Brasil. São eles: 13ª Região, com sede em João Pessoa (Lei n. 7.324/85); 14를 Região, com sede em Porto Velho (Lei n. 7.523/86); 15ª Região, com sede em Campinas (Lei n. 7.520/86) e 16a Região, com sede em São Luís (Lei n. 7.671, de 21 de setembro de 1988). A dinâmica de interiorização da Justiça do Trabalho pelo País também teve continuidade, com a criação de novas JCJs no respectivo período, além das 382 existentes em dezembro de 1994.

Se não bastasse, foi promulgada em 24 de julho de 1985 a paradigmática Lei da Ação Civil Pública (n. 7.347/85). Esse diploma normativo iria se tornar, logo a seguir (especialmente a contar do advento da Constituição de 1988), segundo a jurisprudência que se tornou dominante, amplamente aplicável à seara dos direitos individuais, sociais e ambientais trabalhistas, particularmente os direitos individuais trabalhistas homogêneos, os direitos coletivos trabalhistas e os direitos difusos trabalhistas.

\footnotetext{
${ }^{9}$ Posteriormente ao advento da nova Constituição, outras centrais surgiram no País, seja por criação direta, seja como resultado de fusão ou incorporação entre entidades já estruturadas. Em 2016, por exemplo, o Ministério do Trabalho, nos termos da Lei n. 11.648/2008, certificou a existência de 6 (seis) centrais sindicais que cumpriram o "índice de representatividade" mencionado pela Lei das Centrais Sindicais. (DELGADO, 2017, p. 121).
} 


\title{
6.2 A CONSTITUIÇÃO DE 1988 E A RENOVAÇÃO DEMOCRÁTICA DO DIREITO DO TRABALHO
}

A promulgação da Constituição de 1988 abriu notável era de renovação democrática no Direito do Trabalho brasileiro - era que se mostrou pujante ao longo de 27 anos, provocando modificações de grande relevo.

É sabido que a Constituição de 1988 representa um marco na história político-jurídica do Brasil, sobretudo se considerada a centralidade dada à pessoa humana e ao direito fundamental ao trabalho.

Os destaques acentuados à pessoa humana e ao trabalho são visualizados na nova topografia desenhada pela Constituição e pela compreensão normativa e teórica do paradigma constitucional de 1988, a partir do conceito de dignidade ${ }^{10}$.

A Constituição de 1988, topograficamente, lança mensagem inequívoca:

\begin{abstract}
[...] evidencia a prevalência da pessoa humana em seu interior, certificando em seu frontispício, capítulos e normas iniciais, direitos de caráter individual e social, que ocupam o espaço aberto por todas as Cartas anteriores exclusivamente às entidades estatais da União, Estados, Distrito Federal e Municípios. É relevante, social e politicamente, essa distinção no tratamento jurídico, por se saber incompreensíveis o fato e o conceito de cidadania sem o instrumental e estatuto jurídicos hábeis a lhes conferir consistência prática. O encouraçamento jurídico da noção de cidadania é aspecto importante à sua efetiva configuração social (DELGADO, 1992, p.45-46).
\end{abstract}

O texto constitucional também inovou topograficamente em relação ao direito fundamental ao trabalho digno, ${ }^{11}$ ao deslocar os direitos dos trabalhadores, situados na antiga tradição constitucional no Capítulo da "Ordem Econômica e Social", para inseri-los no Título dedicado aos "Direitos e Garantias Fundamentais", no Capítulo destinado aos "Direitos Sociais". Ou seja, a partir da Constituição de 1988 , os direitos dos trabalhadores "ganharam a qualidade e a estatura de direitos humanos fundamentais" (ABREU, 2001, p.1563).

A nova Constituição da República, a par de enquadrar os direitos individuais e sociais trabalhistas como direitos humanos e, igualmente, direitos fundamentais, considerou estrutural a vinculação dos direitos laborativos à noção principiológica de

\footnotetext{
${ }^{10}$ Sobre o tema da dignidade, consultar: DELGADO, 2006. (2. ed.: 2015).

${ }^{11}$ A respeito, consultar DELGADO, 2006 (2. ed.: 2015).
} 
centralidade da pessoa humana na ordem jurídica e na vida socioeconômica, desde o seu Preâmbulo, passando pelo Título I ("Dos Princípios Fundamentais") e pelo Título II ("Dos Direitos e Garantias Fundamentais"), até atingir os princípios dirigentes da Ordem Econômica e Financeira (Título VII, art. 170) e da Ordem Social (Título VIII, art. 193).

Se não bastasse, a Constituição de 1988 firmou a presença de diversos princípios constitucionais humanistas e sociais, com o objetivo de acentuar a ênfase ao seu direcionamento civilizatório, em contraponto às concepções darwinistas, individualistas e mercadológicas ainda prestigiadas no mundo ocidental. Citem-se, entre esses princípios, aqueles que ostentam correlações significativas com o campo social do Direito e que, por isso, têm sido chamados de "princípios constitucionais do trabalho": princípio da dignidade da pessoa humana; princípio da centralidade da pessoa humana na vida socioeconômica e na ordem jurídica; princípio da valorização do trabalho e do emprego; princípio da inviolabilidade do direito à vida; princípio do bem-estar individual e social; princípio da justiça social; princípio da submissão da propriedade à sua função socioambiental; princípio da não discriminação; princípio da igualdade em sentido material; princípio da segurança; princípio da proporcionalidade e da razoabilidade; princípio da vedação do retrocesso social. ${ }^{12}$

A Constituição de 1988 passa, desse modo, a representar as novas lentes corretoras da CLT, que servem de filtro para uma leitura atualizada de seus dispositivos. Não por coincidência, já em 1989, é aprovado diploma legal direcionado a excluir do diploma celetista diversos dispositivos que, inequivocamente, se mostravam incompatíveis com a nova Constituição da República. Embora a dinâmica da não-recepção seja automática, sem necessidade de diploma legal explícito nessa direção, o fato é que o Parlamento e o Poder Executivo preferiram explicitar e expungir diversas assincronias percebidas no diploma legal oriundo das

\footnotetext{
12 Esse rol de 12 princípios constitucionais humanistas e sociais está estudado em DELGADO, 2017, p. 36-128.
} 
décadas precedentes a cinco de outubro de 1988. É o que se passou, desse modo, com a Lei n. 7.855 , de 24.10.1989. ${ }^{13}$

A nova Constituição da República arquitetou a imediata institucionalização de um Estado Democrático de Direito no País, fundado em seus três pilares cardeais: a pessoa humana, com sua dignidade; a sociedade política, em estruturação democrática e inclusiva; e a sociedade civil, também com estruturação democrática e inclusiva. ${ }^{14}$ Em sua concepção de Estado Democrático de Direito, conforme se percebe, naturalmente que a nova ordem constitucional buscou a instauração de um Estado de Bem-Estar Social no Brasil, única fórmula que tem se mostrado capaz, nos marcos do sistema capitalista, de garantir a formatação democrática e inclusiva das sociedades política e civil, com a firme prevalência da pessoa humana e sua dignidade em suas estruturas, instituições e dinâmicas. ${ }^{15}$

Nos tópicos seguintes, será feita uma síntese das inovações e aperfeiçoamentos trazidos pela Constituição de 1988 nos campos do Direito Individual do Trabalho, do Direito Coletivo do Trabalho e do Direito Processual do Trabalho. Evidentemente que nem todas as inovações e aperfeiçoamentos democráticos e inclusivos foram realizados de imediato, pelo próprio texto constitucional original de 1988. Diversos deles foram realizados nos anos e décadas subsequentes a outubro de 1988, quer por meio de Emendas Constitucionais, quer por meio de novos diplomas internacionais ratificados, quer mediante novas leis aprovadas no País.

\footnotetext{
${ }^{13}$ A Lei n. 7.855/89 revogou, expressamente, os seguintes preceitos da CLT: parágrafo único do art. 16; arts. 18, 19, 27, 28, 43, 44, 324, 374, 375, 378, 379, 380, 387, 418 e 446 da Consolidação. Vários desses preceitos eram referentes à antiga regulação do trabalho das mulheres que, por seu excesso interventivo, passou a ser considerada manifestamente discriminatória das trabalhadoras. É o que se passava, ilustrativamente, com os arts. 374, 375, 378, 379, 380, 387 e 446 da CLT. A propósito, pouco anos depois, a Lei n. 8.630/1993, em seu art. 76, revogou inteiramente o Decreto-Lei $n$. 3/1966 que, provindo do espírito autoritário do regime instalado em 1964 no País, fixara diversos dispositivos que se tornariam incompatíveis com a ordem democrática instituída pela Constituição de 1988 (por exemplo, o antigo parágrafo único do art. 482 da CLT).

${ }^{14}$ Sobre essa concepção constitucional de Estado Democrático de Direito, com o seu tripé conceitual acima indicado (a pessoa humana, com sua dignidade; a sociedade política, democrática e inclusiva; a sociedade civil, também democrática e inclusiva), consultar DELGADO, 2017, p. 33-58.

${ }^{15}$ A respeito das características estruturais do Estado de Bem-Estar Social, que fazem esse modelo de organização social, política, econômica, cultural, jurídica e institucional atender amplamente os requisitos e pilares do Estado Democrático de Direito, consultar os seguintes estudos: ARRETCHE, 2019, p. 50-105; BRIGGS, 2006, p. 16-29; CONDÉ, 2008, p. 23-92; DELGADO; PORTO, 2019, p. 2349; FARIA, 2018. p. 33-78; KERSTENETZKY, 2012, p. 01-36; TITMUSS, 2006, p. 41-47.
} 


\section{A) Direito Individual do Trabalho}

A grande maioria das regras relacionadas ao Direito Individual do Trabalho inseridas na Constituição da República está exposta no art. 7º em seu caput e em seus 34 incisos. Porém há diversos princípios que atuam nessa seara do Direito do Trabalho - como os denominados princípios constitucionais do trabalho (já mencionados neste texto acadêmico) - que emergem também de outros sítios constitucionais, como o Preâmbulo, o Título I, o Capítulo I do Título II, o Título VII e o Título VIII.

Há ainda institutos e conceitos normativos que adentraram, inovadoramente, o Direito Individual do Trabalho provindos do Capítulo I ("Dos Direitos e Deveres Individuais e Coletivos") do Título I ("Dos Direitos e Garantias Fundamentais") da Constituição. O mais impressionante deles reside na ênfase no universo da personalidade da pessoa humana, anteriormente não tão enfatizado no Direito do Trabalho, com suas indenizações por danos morais e danos materiais (as indenizações por danos morais eram apenas excepcionalmente acolhidas no Direito brasileiro antes da CF/88). Tal universo da personalidade do ser humano está firmemente destacado no Preâmbulo, no Título I ("Dos Princípios Fundamentais") e no Capítulo I do Título I, conforme referido. Particularmente, no art. 5o, caput e incisos I, III, IV, V e X, da CF/88, a par de outros incisos, naturalmente. As indenizações por dano material, moral ou à imagem, tão bem explicitadas nos incisos V e X da Constituição de 1988, abriram um campo muito relevante de desenvolvimento do Direito Individual do Trabalho (e, em alguma medida, até mesmo do Direito Coletivo do Trabalho) a partir da promulgação do novo texto constitucional.

Em harmonia a isso também se abriu o campo da infortunística do trabalho, com a possibilidade jurídica de indenizações por dano material, moral e à imagem a serem arcadas diretamente pelo empregador em face de seu empregado lesionado. É o que se pode inferir da combinação do disposto no art. 5\%, caput e incisos $V$ e X, com o disposto nos incisos XXII e XXVIII do art. $7^{\circ}$ da mesma Constituição da República.

Naturalmente que tais matérias relacionadas a essas indenizações igualmente têm de buscar suporte jurídico, em distintos aspectos, no plano do 
Código Civil de 2002, em face de suas diversas regras regentes de tais indenizações.

Outro tema que adentrou, com vigor renovado, o Direito Individual do Trabalho (embora não fosse estranho a esta seara jurídica e também lance reflexos no Direito Coletivo) é o meio ambiente do trabalho. Uma combinação de dispositivos situados em títulos diversos da Constituição da República teve o condão de alargar e aprofundar a perspectiva analítica e jurídica a respeito dos assuntos relacionados ao meio ambiente do trabalho. Citem-se, por exemplo, os seguintes preceitos: no Titulo II, Capítulo II ("Dos Direitos Sociais"), o seu art. $7^{\circ}$, incisos XXII e XXIII; a par disso, no Título VIII, Capítulo VIII ("Do Meio Ambiente"), o seu art. 225; se não bastasse, também no Título VIII, Capítulo II ("Da Seguridade Social"), Seção II ("Da Saúde"), o seu art. 200, caput e incisos II e VIII, todos da CF/88.

Ingressando, por fim, no texto do art. $7^{0}$ da Constituição, cabe pontuar que, por razões metodológicas, far-se-á, neste artigo, apenas uma seleção de preceitos constitucionais direcionados ao Direito Individual do Trabalho, enfocando somente alguns dos mais significativos e impactantes. É que, afinal, existem, no dispositivo da Constituição, nada menos do que 34 preceitos vinculados a essa seara jurídica especializada. Torna-se, portanto, inviável, nos marcos deste artigo acadêmico, realizar o comentário avaliativo sobre todos esses 34 incisos constitucionais.

Nessa seleção pedagógica, percebe-se que o caput do art. $7^{0}$ incorporou 0 princípio trabalhista da norma mais favorável no corpo constitucional, lançando diretriz muito importante para as dinâmicas de elaboração de regras jurídicas, de interpretação de normas jurídicas e também de hierarquização de normas jurídicas.

O mesmo texto constitucional igualou em direitos os empregados urbanos e rurais (art. $7^{\circ}$, caput), concluindo, por fim, o processo de aproximação jurídica inaugurado pela antiga Lei n. 4.214, de 1963 (antigo Estatuto do Trabalhador Rural). Na mesma linha, a Constituição equiparou os direitos dos trabalhadores avulsos aos daqueles obreiros que possuem vínculo empregatício (art. $7^{\circ}$, XXXIV).

Nessa seara de busca de maior inclusão civilizatória, o parágrafo único do art. $7^{\circ}$ aumentou sensivelmente os direitos dos trabalhadores domésticos, deflagrando dinâmica de aperfeiçoamento que produziria outros avanços nos anos seguintes. Dessa maneira, foi dado passo adicional nessa evolução ampliativa dos 
direitos da categoria doméstica por meio da Lei oㅜ 11.324, de 2006. Pouco tempo depois, em 2013, com a EC 72, demarcou-se novo e elevado patamar de conquistas jurídicas, o qual seria ainda mais aperfeiçoado com o advento da Lei Complementar n. 150, de 2015.

A Constituição conferiu novo e destacado estatuto à mulher trabalhadora. Não só firmou a igualdade formal e substancial entre homens e mulheres (art. 50, caput e inciso I), como enfatizou o princípio antidiscriminatório no contexto das relações de trabalho (art. $7^{\circ}$, caput e inciso $\mathrm{XXX}$ ), proibindo a diferença de salários, de exercício de funções e de critério de admissão por motivo de sexo, idade, cor ou estado civil. Garantiu explícita "proteção do mercado de trabalho da mulher, mediante incentivos específicos, nos termos da lei" (art. $7^{\circ}, \mathrm{XX}$; grifos acrescidos). Assegurou licença à gestante, sem prejuízo do emprego e do salário, com duração de 120 dias (art. $7^{\circ}, \mathrm{XVIII}$ ), a par de lhe assegurar a garantia provisória de emprego, desde a confirmação da gravidez até cinco meses após o parto (art. 10, II, "b", do $A D C T)$. Nessa fase de nascimento da criança, assegurou também ao homem a licença-paternidade de cinco dias (art. $7^{\circ}$, XIX, c./c. art. 10, $\S 2^{\circ}$, do ADCT). Em decorrência lógica da proteção à mulher e à criança, a Constituição, por meio da EC n. 53, de 2006, garantiu assistência gratuita aos filhos e dependentes desde 0 nascimento até cinco anos de idade em creches e pré-escolas (art. $7^{\circ}, \mathrm{XXV}$, conforme redação dada pela EC 53/2006 - regra harmônica à fixada no art. 208, IV, conforme redação inserida pela EC 53/06).

Por força desses comandos constitucionais enfáticos, novos diplomas legais surgiram nos anos subsequentes a 1988, combatendo a discriminação e empoderando a posição das mulheres no mercado de trabalho. Citem-se, por ilustração, as Leis n. 7.855/1989, n. 9.029/1995 e n. 9.799/1999. Cite-se também, nessa seara temática, a Lei n. 11.770/2008, que instituiu o Programa Empresa Cidadã, propiciando que o empregador aderente, usufruindo de incentivo fiscal, conceda mais 60 dias de licença-maternidade à mulher parturiente, além de mais 15 dias de licença-paternidade ao pai empregado. Se não bastasse, outros diplomas legais iriam aperfeiçoar a sistemática da licença-maternidade, estendendo-a aos casos de criança adotada (120 dias, segundo a Lei n. 12.010/2009) e também 
inclusive ao empregado que "adotar ou obtiver guarda judicial para fins de adoção" (Lei n. 12.873/2013). ${ }^{16}$

No que concerne à proibição e erradicação do trabalho de crianças e à proteção ao trabalho de adolescentes, a EC n. 20/1998 aperfeiçoou o texto original constitucional de 1988, alterando os parâmetros etários para a capacidade concernente ao trabalho. Assim, desde a EC n. 20, publicada em 16.12.1998, a Constituição passou a proibir qualquer trabalho aos menores de 16 anos, salvo na condição de aprendiz, neste caso a partir dos 14 anos. ${ }^{17}$

Observe-se que essa determinação constitucional - além de outras dimensões civilizatórias que ostenta - harmoniza-se com as normas regentes da educação na Constituição da República, estabelecidas nos artigos 205 até 214 componentes da Seção I ("Da Educação") do Capítulo III ("Da Educação, da Cultura e do Desporto") do Título VIII ("Da Ordem Social") do Texto Magno. Para a Constituição, a "educação, direito de todos e dever do Estado e da família, será promovida e incentivada com a colaboração da sociedade, visando o pleno desenvolvimento da pessoa, seu preparo para o exercício da cidadania e sua qualificação para o trabalho" (art. 205, CF/88; grifos acrescidos). Em coerência, a Constituição Federal determina a garantia de "educação básica obrigatória e gratuita dos 4 (quatro) aos 17 (dezessete) anos de idade, assegurada inclusive sua oferta gratuita para todos os que a ela não tiveram acesso na idade própria" (inciso I do art. 208, conforme redação promovida pela EC n. 59/2009); determina, ademais, a "progressiva universalização do ensino médio gratuito" (inciso II do art. 208, conforme redação inserta pela EC n. 59/2009); se não bastasse, fixa a garantia de "educação infantil, em creche e pré-escola, às crianças até 5 (cinco) anos de idade" (inciso IV do art. 208 da CF, segundo redação dada pela EC n. 53/2006).

Agregue-se que a proibição do trabalho da criança e as restrições e proteções ao trabalho do adolescente harmonizam-se igualmente aos deveres fixados pela Constituição à família, à sociedade e ao Estado no sentido de

\footnotetext{
${ }^{16}$ Os diversos aperfeiçoamentos e inovações na sistemática de concessão de licença-maternidade, com mudanças na Lei Previdenciária n. 8.213/1991 e na CLT, por meio de diplomas legais subsequentes à Constituição de 1988, estão explicitados em DELGADO, 2018, p. 1.277-1281.

17 O texto original de 1988 previa os seguintes limites etários: proibição de qualquer trabalho abaixo de 14 anos, salvo na condição de aprendiz, a partir de 12 anos de idade. Tais parâmetros originais de idade foram elevados, portanto, em dois anos.
} 
"assegurar à criança, ao adolescente e ao jovem, com absoluta prioridade, o direito à vida, à saúde, à alimentação, à educação, ao lazer, à profissionalização, à cultura, à dignidade, ao respeito, à liberdade e à convivência familiar e comunitária, além de colocá-los a salvo de toda forma de negligência, discriminação, exploração, violência, crueldade e opressão" (art. 227, CF, com redação conferida pela EC 65/2010; grifos acrescidos).

Regra constitucional relevante diz respeito à regência normativa do instituto do salário mínimo. Nesse quadro, o art. 7ํㅡㄹ em seus incisos IV e VII, lidos harmonicamente, assegura ao empregado, como piso mínimo civilizatório, o direito ao salário mínimo, compreendido como capaz de "atender às suas necessidades vitais básicas e às de sua família com moradia, alimentação, educação, saúde, lazer, vestuário, higiene, transporte e previdência social ..." (art. $7^{\circ}$, IV; grifos acrescidos). E agrega o inciso VII: "garantia de salário, nunca inferior ao mínimo, para os que percebem remuneração variável". Naturalmente que o salário mínimo referido pelo inciso IV, apto a atender tamanhas necessidades do empregado e de sua família, é o de dimensão mensal, jamais o de dimensão meramente diária ou horária. As frações diárias e horárias do salário mínimo são simples instrumentos para cálculos contábeis no contexto trabalhista, porém, evidentemente, não atendem os dois inequívocos comandos fixados pela Constituição em seu art. $7^{\circ}$, incisos IV e VII, interpretados com lógica e sistematicidade.

Afora os diversos outros dispositivos sobre Direito Individual do Trabalho existentes no art. $7^{\circ}$ da Constituição, cabe se ressaltar que o espírito humanista, social, democrático e inclusivo da nova Constituição da República inspirou a ratificação, pelo Brasil, de dezenas de diplomas normativos internacionais com influência no campo jusindividual trabalhista. Note-se que apenas no tocante a convenções internacionais da OIT, foram ratificadas pelo Congresso Nacional mais de 30 (trinta) diplomas internacionais, sobre os mais variados campos do Direito Material do Trabalho, seja individual, seja coletivo. A maior parte dessas convenções ratificadas, naturalmente, situa-se no segmento do Direito Individual do Trabalho. Citem-se os números de várias delas - consideradas apenas aquelas cujo Decreto Legislativo de ratificação tenha sido aprovado a partir de cinco de outubro de 1988 : Convenções n. 102, 119, 126, 133, 134, 136, 137, 140, 141, 144, 146, 147, 151, 
$152,154,155,159,160,161,162,163,164,166,167,168,169,170,171,174,176$, 178,182 e 185.

O mesmo espírito humanista, social, democrático e inclusivo da Constituição de 1988 inspirou a ratificação, pelo Brasil, de diplomas internacionais da Organização das Nações Unidas com forte influência no campo jusindividual trabalhista brasileiro. Cite-se, nesse quadro, a Convenção Internacional sobre os Direitos das Pessoas com Deficiência e seu Protocolo Facultativo, ratificada pelo Decreto Legislativo n. 186, de 9 de julho de 2008.

Sob influência desse mesmo espírito democrático e inclusivo, diversos diplomas legais de aperfeiçoamento da ordem jurídica trabalhista foram promulgados nos 27 anos de vigência da Constituição da República, entre os anos de 1988 e 2015 - vários deles, inclusive, já mencionados neste artigo acadêmico.

B) Direito Coletivo do Trabalho

O texto original da Constituição de 1988 trouxe imediatas e importantes mudanças e aperfeiçoamentos para o Direito Coletivo do Trabalho, em comparação com o paradigma oriundo das décadas de 1930/40.

Ao consagrar, pela primeira vez na história constitucional brasileira, com clareza, os princípios da liberdade associativa e sindical e da autonomia das entidades sindicais (art. 8o, I e II, CF/88), a nova Constituição eliminou o controle político-administrativo do Ministério do Trabalho sobre os sindicatos. E, de fato, nas décadas seguintes não se teve notícia de intervenções ministeriais em sindicatos, nem "vetos" a chapas ou nomes integrantes de chapas disputantes em pleitos de entes sindicais.

A Constituição de 1988, também pioneiramente, reconheceu a validade e a amplitude do direito de greve, "competindo aos trabalhadores decidir sobre a oportunidade de exercê-lo e sobre os interesses que devam por meio dele defender" (art. 9ํ, caput, CF/88). Embora não tivesse instituído um direito de caráter absoluto, uma vez que os próprios $\S \S 1^{\circ}$ e $2^{\circ}$ do art. 9ำ fixam fronteiras ao exercício dos movimentos paredistas, o fato é que estabeleceu novo direito individual e coletivo fundamental constitucional, com status jamais alcançado na história constitucional precedente do País. 
A nova Constituição, ademais, consagrou ampla prerrogativa aos sindicatos para que atuem em defesa dos direitos e interesses individuais da categoria, inclusive em questões judiciais ou administrativas (art. 8ํㅡ. III, CF/88). Em coerência com esses amplos poderes e prerrogativas firmados, o inciso VI do mesmo art. $8^{\circ}$ declarou ser "obrigatória a participação dos sindicatos nas negociações coletivas de trabalho".

No tocante à negociação coletiva trabalhista, houve manifesto incentivo constitucional ao seu desabrochar e desenvolvimento (art. 8ㅇ, III e Vl; art. 9; art. 7º, caput e incisos VI, XIII, XIV e XXVI, todos da CF/88 - preceitos a serem lidos, necessariamente, em conjugação harmônica). No paradigma normativo anterior, a negociação coletiva trabalhista não era realmente incentivada; ao invés, era claramente desestimulada, pois a precedente ordem jurídica induzia a solução das questões coletivas entre as partes essencialmente por meio do processo judicial de dissídio coletivo e respectivo poder normativo judicial trabalhista. Sob essa perspectiva, assim, houve clara inovação e aperfeiçoamento no Direito Coletivo do Trabalho brasileiro.

Evidentemente que o incentivo constitucional à negociação coletiva trabalhista não traduz a instituição de mecanismo apto a desagregar o patamar civilizatório mínimo fixado pela legislação heterônoma estatal, formada pela Constituição da República, pelas normas internacionais imperativas no Brasil regentes dos direitos individuais, sociais e coletivos trabalhistas (direitos humanos econômicos, sociais e culturais), a par da legislação federal cogente. Como próprio à cultura jurídica ocidental mais avançada, a negociação coletiva trabalhista é veículo de aperfeiçoamento, avanço e adequação das normas jurídicas heterônomas estatais, e não de sua descaracterização e descumprimento.

Além desses quatro relevantes aperfeiçoamentos no Direito Coletivo do Trabalho, a Constituição de 1988, tempos depois, por meio de emendas constitucionais, continuou sua trilha de melhorias nesse segmento jurídico especializado. Assim, por intermédio da EC n. 24, de 1999, extinguiu a representação classista sindical na Justiça do Trabalho, expungindo esse viés corporativista que ainda permanecia no sistema sindical e judicial brasileiro. Trata- 
se, pois, da quinta relevante mudança ocorrida em face do novo espírito constitucional deflagrado no País.

A par disso, por intermédio da EC n. 45, de 2004, a Constituição da República restringiu bastante o caminho judicial de solução de conflitos trabalhistas - o poder normativo e sua ação de dissídio coletivo -, deixando aberto esse caminho apenas nos casos em que houvesse "comum acordo" entre as partes para a propositura da ação coletiva (situação de raríssima ocorrência na prática, conforme se pode imaginar) e em situações comprovadas de movimentos grevistas deflagrados (novo texto do $\S 2^{\circ}$ do art. 114 da CF/88 e conseqüente jurisprudência formada sobre sua compreensão). Com esse aperfeiçoamento normativo e jurisprudencial - o sexto efetivado sob a vigência da nova Constituição da República -, o poder normativo deixou de cumprir seu antigo papel de concorrente estatal da negociação coletiva trabalhista.

O espírito constitucional de 1988 promoveu também a ratificação de duas importantes convenções internacionais da OIT relacionadas ao Direito Coletivo do Trabalho: a Convenção n. 135, ratificada pelo Decreto Legislativo n. 86, de 14.12.1989; e a Convenção n. 151, ratificada pelo Decreto Legislativo n. 206, de 07.04.2010.

A Lei de Centrais Sindicais, promulgada em 2008, consistiu em outro notável avanço civilizatório no Direito Sindical do País. Além de institucionalizar essas importantes entidades dirigentes do sindicalismo brasileiro - respeitada a diversidade de sua orientação político-filosófica -, a Lei n. 11.648/08 estipulou a necessidade de superação da contribuição sindical obrigatória (esta, um nítido viés corporativista do antigo sistema sindical brasileiro). E o fez mediante a instigação à prudente regulação legal da contribuição negocial (doutrinariamente denominada ainda de "cota de solidariedade"), decorrente do efetivo exercício da negociação coletiva trabalhista pelas entidades sindicais (art. $7^{\circ}$ da Lei das Centrais Sindicais). Em síntese, a par de aprofundar a reverência aos princípios da liberdade sindical e da autonomia dos sindicatos na ordem jurídica brasileira (o primeiro aperfeiçoamento apontado neste subitem referente ao Direito Coletivo), a Lei das Centrais Sindicais apontou na direção democrática e equilibrada para a superação de um viés característico do antigo sistema sindical estruturado nas décadas de 1930/40 (a 
contribuição sindical obrigatória) - o que poderia se tornar o sétimo aperfeiçoamento relevante no Direito Coletivo do Trabalho do País.

A Constituição de 1988 preferiu não alterar a regra tradicional da unicidade sindical por força de norma jurídica, surgida na década de 1930 no sistema sindical brasileiro. Ao invés, constitucionalizou essa regra jurídica - que se mostra, de certo modo, antitética ao espírito democrático amplo da própria Constituição.

A respeito da unicidade sindical constitucionalizada, sedimentou-se, lamentavelmente, nos anos seguintes a 1988, na jurisprudência do TST e do STF, a compreensão de que o critério de representatividade das entidades sindicais brasileiras, particularmente os sindicatos, deve se fundar no "princípio da especialização", oriundo do Direito Civil, ao invés do "princípio da agregação" - este tendente a reforçar e empoderar os sindicatos existentes no País. Na esteira dessa jurisprudência amplamente dominante, generalizou-se, desde os anos 1990, o fracionamento e a pulverização dos sindicatos brasileiros, dando origem a números dantescos de entidades sindicais no Brasil (mais de 10 mil sindicatos obreiros no País, ilustrativamente) - entidades sindicais bem especializadas, é bem verdade, porém bastante modestas e enfraquecidas, infelizmente. ${ }^{18}$

Por fim, conforme já foi enfatizado neste estudo acadêmico, a partir de cinco de outubro de 1988, a nova Constituição da República representa, necessariamente, as novas lentes corretoras da CLT, que servem como filtro para uma leitura atualizada de seus dispositivos.

C) Direito Processual do Trabalho

O texto original da Constituição de 1988 determinou a plena inserção e capilaridade da Justiça do Trabalho em todo o território nacional, por intermédio da criação de um TRT em cada Estado da Federação (art. 112, CF/88). Nesse contexto, em cerca de apenas quatro anos, foram criados mais 8 (oito) TRTs, atingindo, dessa maneira, todos os Estados com população de, pelo menos, dois milhões de

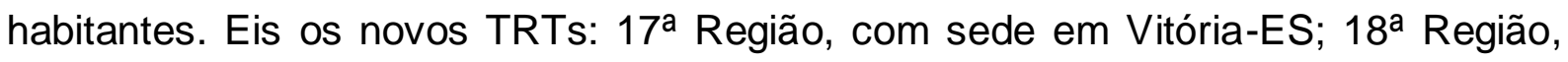

\footnotetext{
18 Dados divulgados pelo Ministério do Trabalho, em 2016, informavam a existência de 10.926 sindicatos de trabalhadores no Brasil, conforme despacho do Ministro do Trabalho publicado no Diário Oficial da União em 01.04.2016. Essa lista consta da "Relação de Centrais Sindicais Certificadas", com referência a 2016, em conformidade com determinação feita pela Lei das Centrais Sindicais (n. 11.648/08). Tais dados e sua análise estão contidos em DELGADO, 2017, p. 74-77.
} 
com sede em Goiânia-GO; 19ํㅡ Região, com sede em Maceió-AL; 20ํำ Região, com sede em Aracaju-SE; 21 ${ }^{a}$ Região, com sede em Natal-RN; 22 ${ }^{a}$ Região, com sede em

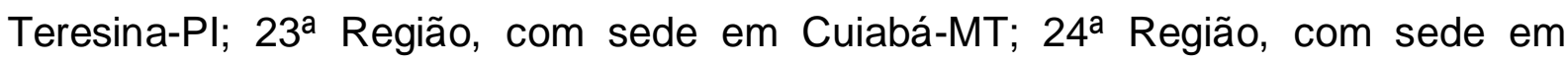
Campo Grande-MS.

A dinâmica de interiorização da Justiça do Trabalho ao longo de todo o País mereceu, em conseqüência, forte impulso desde a promulgação da nova Constituição. Nesse quadro, criou-se, em cerca de 27 anos de existência da Constituição (1988-2015), mais de um milhar de novas Varas Trabalhistas no Brasil, diversas delas com a presença de dois Magistrados (um Juiz Titular e um Juiz Substituto, ambos atuando com independência funcional mas em parceria, em benefício da produção e produtividade processuais). Do número de $382 \mathrm{JCJ}$ existentes em dezembro de 1984 (final do regime civil-militar autoritário), passou-se ao número de cerca de 1.600 Varas Trabalhistas em dezembro de 2015, todas, necessariamente, com uma vaga de Juiz Titular, ao passo que também existiam, na mesma data (ainda que não exatamente providos até o final de 2015), em torno de 3.360 cargos de Juiz Substituto ao longo de todo o território nacional. Com isso, a capilaridade e a eficiência da Justiça do Trabalho se aperfeiçoaram nas diversas regiões do País. ${ }^{19}$

Esses avanços propiciados pela Constituição de 1988 e seu espírito e direcionamento democráticos e inclusivos harmonizavam-se à compreensão constitucional de ser imprescindível a ampliação do acesso à jurisdição trabalhista no País, no contexto de um clássico reconhecimento de que o processo do trabalho e o ramo judicial trabalhista se constituíam em um dos segmentos mais simples, objetivos, eficientes e céleres de todo o sistema judicial.

Em coerência com essa avaliação, diversas micro reformas feitas no Código de Processo Civil de 1973, nas décadas de 1990 e 2000, fundaram-se na extensão de institutos e práticas funcionais típicas do Direito Processual do Trabalho, tornando mais simples, célere e eficiente o próprio Direito Processual Civil brasileiro de então.

\footnotetext{
${ }^{19}$ Com a extinção da representação classista na Justiça do Trabalho, promovida pela EC n. 24/1999, as JCJs desapareceram, sendo substituídas pelas Varas do Trabalho, com seu respectivo Juiz Titular. Em cada Vara com maior movimento processual tende a atuar, concomitantemente ao Juiz Titular, um Juiz Substituto.
} 
Esse processo de aperfeiçoamento e racionalização do sistema processual trabalhista brasileiro atingiu o seu ápice, no campo justrabalhista, com a Emenda Constitucional n. 45, de dezembro de 2004, que implementou a denominada reforma do Judiciário. Por esse reforma constitucional, ampliou-se a competência jurisdicional da Justiça do Trabalho (nova redação do art. 114 da CF/88), buscando concentrar nesse segmento do Poder Judiciário todas as matérias principais e conexas vinculadas às relações trabalhistas. Embora a jurisprudência subsequente decantasse, pela via interpretativa, essa ampliação de competência, o fato é que ela, de todo modo, se alargou e se viu mais racionalizada em comparação com o período histórico e jurídico anterior.

A EC n. 45 considerou também cumprido o objetivo constitucional de 1988 no sentido de se efetivar, com rapidez, maior capilaridade à Justiça do Trabalho em todo o território brasileiro; é que, em 2004, já se encontravam criados e instalados 24 TRTs no País, abrangendo, dessa maneira, todos os Estados com população igual ou maior do que 2 milhões de habitantes. Em consequência, a EC n. 45 alterou a regra originalmente inserida no art. 112 da Constituição, eliminando a necessidade de instituição de tribunais do trabalho inclusive em Estados com modesta densidade populacional.

No que diz respeito à Corte Superior Trabalhista, a EC 45/04 restaurou dez cargos judiciais no TST, de modo a retornar aos 27 cargos ministeriais existentes até a data da extinção da representação classista na Justiça do Trabalho, promovida pela EC 24, de 09.12.1999. Essa recriação de 10 vagas de Magistrados no TST ampliou-lhe a
composição em quase $60 \%$, com o provimento efetivo de novos Ministros
consumando-se nos anos de 2006 e 2007 , no contexto de uma conjuntura
institucional de notável reforço aos direitos fundamentais trabalhistas. Tudo
isso propiciou, logo a seguir, significativa evolução e aperfeiçoamento na
dinâmica jurisprudencial da Corte Superior Trabalhista, em conformidade
com as diretrizes da Constituição Federal de 1988 (DELGADO, 2013, p.7-
8).

Por fim, a EC n. 45 restringiu, significativamente, a amplitude da ação judicial de dissídio coletivo de natureza econômica e, por consequência, a força e amplitude do poder normativo da Justiça do Trabalho. E o fez mediante a inserção, no $\S 2^{\circ}$ do 
art. 114, de novo pressuposto processual de difícil e rara consecução, ou seja, a prévia existência de comum acordo para a propositura da ação coletiva judicial. Com essa inovação, a reforma do Judiciário, indiretamente, reforçou ainda mais a dinâmica da negociação coletiva trabalhista, diminuindo a presença do concorrente judicial consubstanciado no dissídio coletivo de natureza econômica. Mas a reforma , p.constitucional teve a sabedoria de não eliminar, por inteiro, o poder normativo, que restou mantido para os casos de dissídios coletivos de greve e para as situações raras de cumprimento do novo e inusitado pressuposto processual (prévio comum acordo). A par disso, foi também preservado o dissídio coletivo de natureza jurídica - embora este, tradicionalmente, sempre fosse mais raramente utilizado no âmbito processual trabalhista.

Finalmente, considerado o período histórico até 2015, dois novos diplomas legais iriam ainda impactar o Direito Processual do Trabalho brasileiro. Trata-se da Lei n. 13.015, publicada em 22.7.2014 e vigorante desde 20 de setembro de 2014. Em época próxima, o novo Código de Processo Civil, de 13.3.2015, vigorante desde 18 de março de 2016.

A Lei n. 13.015/2014 alterou regras concernentes ao processo do trabalho no âmbito do TST e também nos TRTs, buscando criar novas fórmulas de alcance de mais firme uniformização jurisprudencial no âmbito da Justiça do Trabalho.

O novo CPC, por sua vez - aplicável subsidiária e supletivamente ao Processo do Trabalho -, também trouxe grandes inovações no fluxo dos processos judiciais em todos os segmentos do Poder Judiciário e, por consequência, inclusive na Justiça do Trabalho.

Uma análise circunstanciada desses dois diplomas legais, entretanto, por sua complexidade e extensão, deve ser direcionada a outro texto acadêmico específico, mostrando-se inviável nos limites do presente artigo. 


\section{DESAFIOS DO TEMPO PRESENTE: REFLUXOS À PROTEÇÃO E INCLUSÃO DA PESSOA HUMANA TRABALHADORA E DO TRABALHO NO DIREITO BRASILEIRO}

Os 85 anos iniciais de existência do sistema trabalhista brasileiro (19302015), em seus três planos - Direito Individual do Trabalho, Direito Coletivo do Trabalho e Direito Processual do Trabalho -, traduziram fases históricas, institucionais e jurídicas de fluxos e refluxos no tocante à proteção e à inclusão da pessoa humana trabalhadora e do trabalho no Brasil República.

No balanço objetivo equilibrado desse período de quase nove décadas pode-se aquilatar, principalmente à luz das inovações e aperfeiçoamentos trazidos pela Constituição de 1988 e seu espírito humanista, democrático e social - conforme foi efetivado neste artigo acadêmico -, que as fases e intensidades dos fluxos positivos foram significativamente superiores às fases e intensidades dos refluxos anticivilizatórios.

A partir de 2016, contudo, iniciou-se período de intenso e generalizado refluxo no padrão de proteção e inclusão da pessoa humana trabalhadora e do trabalho no Direito brasileiro. E tal intenso refluxo atingiu, fortemente, todos os planos da seara trabalhista, quer o Direito Individual, quer o Direito Coletivo, que o Direito Processual do Trabalho. A lógica e o direcionamento desse refluxo podem, em certa medida, ser enquadrados como parte das dinâmicas disruptivas verificadas, nas últimas décadas, na seara socioeconômica das relações trabalhistas, integradas a um processo amplo do sistema capitalista de gerar "novas morfologias do trabalho", conforme expõe o sociólogo Ricardo Antunes, "cujo elemento mais visível é seu desenho multifacetado, resultado de fortes mutações que abalaram o mundo do capital nas últimas décadas" (ANTUNES, 2009, p.257). Contudo, por sua intensidade e generalidade avassaladoras, esse recente período de refluxo chega a ultrapassar a mera lógica dessas dinâmicas disruptivas gerais do capitalismo ocidental contemporâneo.

O centro desse período de refluxo encontra-se na Lei n. 13.467, publicada em 14.07.2017 e vigente desde 11 de novembro do mesmo ano. Nos três planos da seara jurídica laborativa, o diploma legal que implementou a reforma trabalhista no 
País trouxe enormes impactos e restrições de direitos, seja diretamente, seja por meio de mudanças restritivas em institutos e práticas protetoras de direitos trabalhistas.

A amplitude da reforma legal de 2017 (mais de 150 regras e institutos jurídicos da CLT foram alterados) inviabiliza que se faça, nos marcos deste artigo acadêmico, sua análise detalhada - a qual, de toda maneira, já tem sido satisfatoriamente realizada pela doutrina justrabalhista pátria ${ }^{20}$. Aponta-se aqui, desse modo, sinteticamente, apenas o sentido principal da Lei n. 13.467/2017 nos três planos centrais de estruturação das instituições e diplomas jurídicos trabalhistas. Nesse apontamento, serão enfocadas as razões pelas quais se compreende se tratar do mais impactante período de refluxo, desde 1930, na proteção e inclusão da pessoa humana trabalhadora e do trabalho no Brasil República.

No plano do Direito Individual do Trabalho, a Lei n. 13.467/07 rebaixou, substancialmente, o patamar civilizatório mínimo justrabalhista até então vigente no País. De fato, vários direitos trabalhistas tiveram sua abrangência profundamente reduzida, quer mediante a restrição do próprio conceito do respectivo direito, quer mediante a restrição de sua área de incidência. Citem-se, ilustrativamente: diminuição do tempo à disposição remunerado (art. $4^{\circ}$, $\S \S 1^{\circ}$ e e $2^{\circ}, \mathrm{CLT}$ ); fixação restritiva do início da jornada de trabalho (art. 58, § 2º remuneração dos feriados no regime de plantão $12 \times 36$ horas (art. 59-A, CLT); alargamento do regime compensatório de horários, inclusive do banco de horas (art. 59, caput e seus parágrafos, CLT); diminuição da retribuição material pelos

20 São inúmeras as obras publicadas a respeito da reforma trabalhista implementada pela Lei $\mathrm{n}$. 13.467/2017. Citem-se, ilustrativamente, alguns dos livros e artigos divulgados no País desde 2017 sobre o assunto: ALENCAR, 2017; ALMEIDA, 2015; ALMEIDA, 2018, p. 26-35; ALVES; CASTRO, 2018, p. 64-76; ARANTES; LEMOS, 2017, p. 99-100; BIAVASCHI, 2017; CASSAR, 2017; CORREIA; MIESSA, 2018; DELGADO, 2017 (17. ed.: 2018); DELGADO; DELGADO, 2017; DIAS; et. al., 2018; DOSSIE REFORMA TRABALHISTA, 2017; ESTEVES, et al., 2018, p. 87-92; FELICIANO; TREVISO; FONTES, 2017; FELICIANO; CONFORTI; PORTO, 2017; GARCIA, 2017; GUNTHER; ALVARENGA; SCHIO, 2018; HORTA; FABIANO; KOURY; OLIVEIRA, 2018; KREIN; GIMENEZ; SANTOS, 2018; LIMA; LIMA, 2017; MELO; ROCHA, 2017; MIESSA; CORREIA; MIZIARA; LENZA, 2017; MIESSA, 2015; MINISTÉRIO PÚBLICO DO TRABALHO, 2017; NAHAS; PEREIRA; MIZIARA, 2017; OLIVEIRA, 2018; OLIVEIRA, 2017; PIRES; LORENTZ; BARBOSA, 2019; PIRES, 2017; PRETTI, 2017; ROCHA, 2017; SCALÉRCIO; MINTO, 2017; SCHIAVI, 2017; SEVERO; MAIOR, 2017; SILVA, 2017; SOUZA JÚNIOR; SOUZA; MARANHÃO; AZEVEDO NETO, 2018; TEIXEIRA FILHO, 2017; TEIXEIRA, et. al., 2017; VEIGA, 2017. 
intervalos descumpridos (art. 71, § 4, CLT); estratificação e exclusão jurídicas dos empregados mais qualificados e com melhores salários, conforme critérios do parágrafo único do art. 444 da CLT; descaracterização salarial de algumas parcelas econômicas existentes no contrato de trabalho (art. 457, CLT); diminuição do sentido e abrangência do instituto da equiparação salarial (art. 461, CLT); eliminação de proteções normativas às dispensas coletivas (art. 477-A, CLT).

Outros direitos foram simplesmente extintos. Por exemplo: horas in itinere (antes reguladas pelo texto do art. 58 da CLT); intervalo de 15 minutos para as mulheres, antecedente ao seu início de trabalho em sobrejornada (antigo art. 384 da CLT); incorporação salarial da gratificação de função recebida por 10 ou mais anos no emprego (art. $468, \S 2^{\circ}$, CLT).

Novos institutos e procedimentos foram criados, com o sentido de restrição de direitos e garantias jurídicas. Nessa linha, mencionem-se a regulação do trabalho intermitente (arts. 443 e 452-A, CLT); o incentivo ao trabalho autônomo, não empregatício, na empresa (art. 442-B, CLT); a generalização da terceirização trabalhista (mudanças implementadas na Lei n. 6.019/1974); os novos dispositivos reguladores das indenizações por danos extrapatrimoniais (arts. 223-A até 223-G da CLT); eliminação da assistência sindical e/ou da assistência administrativa nas rescisões de contratos com mais de um ano de existência (art. 477, CLT); permissão para a pactuação de cláusula compromissória de arbitragem em contratos de empregados que recebam remuneração em valor acima do dobro do teto previdenciário do INSS (art. 507-A, CLT); permissão para quitação anual de obrigações trabalhistas perante 0 sindicato dos empregados da categoria profissional (art. 507-B, CLT).

Somem-se a esses procedimentos restritivos 0 alargamento dos poderes da negociação coletiva na direção da flexibilização dos direitos trabalhistas (art. 611-A, CLT), a par da criação de diversas restrições e penalidades no campo processual trabalhista, diminuindo ou, em certos casos, inviabilizando o acesso dos trabalhadores ao Poder Judiciário do País, quer individualmente, quer por intermédio de suas entidades sindicais. Tais tópicos referentes ao Direito Coletivo e ao Direito Processual, a propósito, serão examinados a seguir. 
Esclareça-se, por fim, que nem todas as regras da Lei n. 13.467/2017 referentes ao Direito Individual do Trabalho ostentam semelhante caráter restritivo; porém, lamentavelmente, a ampla maioria de seus dispositivos perfilam, como visto, o caminho da diminuição do patamar civilizatório mínimo assentado, até então, pelo Direito do Trabalho na História da República.

No plano do Direito Coletivo do Trabalho, a Lei n. 13.467/07 alargou, conforme antecipado, os poderes da negociação coletiva trabalhista, permitindo a esse instituto flexibilizar inúmeras parcelas e garantias laborais, mesmo quando decorrentes de lei (arts. 616-A e 616-B da CLT). Mas, curiosamente, a mesma Lei $n$. 13.467/2017 enfraqueceu sobremaneira os sindicatos de trabalhadores na realidade brasileira, ao extinguir, de imediato (sem qualquer critério de transição), a contribuição sindical obrigatória e, ao mesmo tempo, não convalidar, alternativamente, a contribuição negocial coletiva (também denominada "cota de solidariedade") fixada nos documentos coletivos negociados (arts. 545, 578, 579, 582, 583, 587, 601, 602 e 604 da CLT combinados com art. 611-B, XXVI, da CLT). Ou seja, o diploma legal de 2017 fechou, de uma só vez, dois canais de financiamento do sistema sindical brasileiro, com efeitos jurídicos imediatos a contar de 11.11.2017, no exato instante em que alargou os poderes supressórios de direitos e garantias trabalhistas do instituto negocial coletivo.

É bem verdade que a Lei n. 13.467/2017 instituiu a Comissão de Representação de Empregados nas empresas com mais de 200 empregados, suprindo uma omissão antiga existente no Direito Coletivo do Trabalho do Brasil (arts. 510-A até 510-D da CLT). Porém não estabeleceu laços entre essas comissões internas obreiras e o respectivo sindicato profissional - lacuna que enfraquece, sobremaneira, o novo instituto trabalhista.

De todo modo, infelizmente, essa inovação não supre o dramático enfraquecimento do sindicalismo de trabalhadores no País operado pela Lei $n$. $13.467 / 2017$, nem os riscos abertos pelo novo formato legal da negociação coletiva trabalhista. No balanço de regras e institutos criados ou alterados, o fato é que a nova legislação produziu um inegável refluxo na proteção à pessoa humana trabalhadora e ao trabalho no Brasil República também no plano do Direito Coletivo Trabalhista. 
No plano do Direito Processual do Trabalho, a Lei n. 13.467/07 teve como principal característica restringir, acentuadamente, o acesso ao Poder Judiciário dos trabalhadores brasileiros, mediante a combinação de inúmeros preceitos e institutos jurídicos desproporcionalmente rigorosos. Com essa grave restrição ao acesso dos titulares dos direitos trabalhistas à Justiça do Trabalho, o novo diploma legal completou o quadro de rebaixamento do patamar civilizatório mínimo trabalhista na República brasileira arquitetado pela Lei da Reforma Trabalhista.

Citem-se alguns desses vários preceitos restritivos: descaracterização do instituto constitucional da justiça gratuita, apenando o beneficiário dessa garantia processual fundamental (art. 789, $\S \S 3^{\circ}$ e $4^{\circ}$, , CLT); alteração das regras trabalhistas relativas aos honorários periciais, apenando também o beneficiário da justiça gratuita (art. 790-B, caput e $\S \S 1^{\circ}$ até $4^{\circ}, \mathrm{CLT}$ ); alteração das regras trabalhistas relativas aos honorários advocatícios, inclusive com sucumbência recíproca e sucumbência em reconvenção, no mesmo sentido das mudanças retro mencionadas (art. 791-A, caput e $\S \S 1^{\circ}$ até $5^{\circ}, \mathrm{CLT}$ ); acentuação do rigor formal das petições iniciais trabalhistas (art. 840, caput e $\S \S 1^{\circ}$ até $3^{\circ}, \mathrm{CLT}$ ); restrições diversas à efetividade do processo de execução trabalhista (CLT: art. 876, parágrafo único, c./c. art. 878; art. 879, § 7º; art. 882; art. 889, § 4º c./c. revogação do § 50 do mesmo art. 899; inserção dos $\S \S 9^{\circ}$ até 11 no art. 899); acentuação do formalismo no processo do trabalho, em todas as suas fases, inclusive na fase recursal. ${ }^{21}$

Em síntese, o somatório das inovações e mudanças ocorridas nos três planos da ordem jurídica trabalhista evidenciam a profundidade da fase de refluxo na proteção e inclusão da pessoa humana trabalhadora e do trabalho recentemente deflagrada na História do Brasil República.

\footnotetext{
${ }^{21}$ Análise circunstanciada dessas inúmeras alterações processuais encontra-se na ampla bibliografia especializada referida na nota de rodapé n. 28 deste artigo acadêmico. Nos marcos do presente texto, torna-se inviável e inadequado realizar-se o estudo comentado de todas essas mudanças.
} 


\section{CONCLUSÃO}

Este artigo acadêmico cumpriu o seu objetivo de estudar a dinâmica institucional e jurídica de proteção e inclusão da pessoa humana trabalhadora e do próprio trabalho na ordem jurídica da República do Brasil.

Embora o enfoque central do artigo tenha se situado nas mudanças e avanços propiciados pela Constituição Federal de 1988 na estrutura do sistema trabalhista brasileiro oriundo das décadas de 1930 e 1940 - mudanças que traduziram enorme fluxo de correções e aperfeiçoamentos no sistema trabalhista pátrio -, ele se voltou, ainda, para a análise da fase imediatamente posterior, iniciada em 2016, que tem trazido impactantes refluxos no sistema de proteção e inclusão da pessoa humana e do trabalho no Brasil República.

Para cumprir o seu objetivo, este estudo acadêmico teve de perpassar por momentos históricos anteriores a 1988 na era republicana brasileira. Nessa medida, o artigo iniciou-se com o exame, ainda que sumário, das peculiaridades trabalhistas do período conhecido como "Primeira República", que se estende de 1889 até 1930. Conforme explicitado no artigo, nessa fase histórica mais remota, mostrou-se parca e rarefeita a institucionalidade trabalhista no País, sem a presença de uma complexidade de diplomas legais configuradores de um todo diversificado, orgânico e sistemático apto a configurar, efetivamente, um segmento jurídico plenamente consagrado. A par disso, tal fase também não ostentou a organização de um movimento sindical robusto, diversificado e poderoso, apto a deflagrar, na época, algo como um sistema trabalhista baseado na negociação coletiva trabalhista, ao invés de na normatividade heterônoma do Estado. O fato é que, em síntese, nem legislação trabalhista ampla e diversificada, nem negociação coletiva trabalhista diversificada e abrangente foram características desse período rudimentar no campo da proteção e inclusão da pessoa humana trabalhadora e do trabalho na História do Brasil.

$\mathrm{Na}$ evolução histórica republicana, o segundo momento de destaque reside na fase de 1930 até 1943 (data de aprovação da Consolidação das Leis do Trabalho) ou até 1945 (data da queda do Governo Vargas, que fora iniciado com a Revolução de 1930). Nesse período é que se construiu grande parte das instituições 
e do próprio campo jurídico trabalhista, em seus distintos segmentos, particularmente o Direito Individual do Trabalho, o Direito Coletivo do Trabalho e o Direito Processual do Trabalho. O artigo acadêmico, a propósito, demonstrou que essa importante era de novos direitos e instituições trabalhistas constituiu-se em um fluxo de proteção e inclusão, embora também apresentasse, ao mesmo tempo, vieses autoritários inegáveis, em especial no plano das instituições e práticas coletivas laborais.

O artigo acadêmico também evidenciou que o sistema trabalhista arquitetado e desenvolvido nos 13/15 anos transcorridos desde a Revolução de 1930 manteve-se firme por cerca de cinco décadas, passando pela República Democrático-Desenvolvimentista (1945-1964) e pelo regime civil-militar autoritário (1964-1985). Nesse quadro, o período situado entre 1945 e 1964 caracterizou-se pela preponderância de fluxos de proteção e inclusão trabalhistas, ao passo que o período situado entre 1964 e 1985 alternou situações de grave refluxo desprotetivo e excludente com a presença de certos fluxos de afirmação dos objetivos históricos do Direito do Trabalho, no sentido da proteção e inclusão socioeconômicas.

Após ter cumprido esse necessário escorço histórico-jurídico, o texto acadêmico concentrou-se na paradigmática era deflagrada pela Constituição da República Federativa do Brasil, promulgada em outubro de 1988. Nesse contexto, buscou indicar os aspectos jurídicos e institucionais que melhor traduziram fluxos de proteção e inclusão civilizatórias, considerando menos relevantes - no conjunto comparativo geral dessa era - as situações ou aspectos que apontaram na direção contrária.

O presente artigo, por fim, analisou a fase iniciada no ano de 2016, que tem se caracterizado por grave refluxo na linha de proteção e inclusão da pessoa humana trabalhadora e do trabalho no Brasil República. O texto tomou como parâmetro mais significativo dessa fase a reforma trabalhista implementada pela Lei n. 13.467, de 13.7.2017 - vigente desde 11 de novembro de 2017. $\mathrm{Na}$ análise desse diploma legal, o estudo acadêmico procurou expor os aspectos jurídicos e institucionais modificados pela reforma normativa, os quais afetaram, de modo bastante forte, o sentido de proteção e inclusão da pessoa humana trabalhadora e do trabalho na ordem jurídica do País. 


\section{REFERÊNCIAS}

ABREU, Alzira Alves de, et. al. (Coord.). Dicionário Histórico-Biográfico Brasileiro. Pós-1930. Rio de Janeiro: Editora FGV; CPDOC, 2001.

ALENCAR, Zilmara; Departamento Intersindical de Assessoria Parlamentar. A Face Sindical da Reforma Trabalhista - Lei n. 13.467, de 13 de julho de 2017. Brasília: Departamento Intersindical de Assessoria Parlamentar/Zilmara Alencar Consultoria Jurídica, 2017.

ALMEIDA, Cléber Lúcio. Incidente de Desconsideração da Personalidade Jurídica. In: MIESSA, Élisson (Org.) O Novo Código de Processo Civil e Seus Reflexos no Processo do Trabalho. Salvador: JusPodivm, 2015.

ALMEIDA, Cléber Lúcio de. A Regra da Prevalência do Negociado sobre o Legislado na Perspectiva da Reforma Trabalhista: Rumo à Mutação Genética do Direito do Trabalho no Brasil. In Revista Direito das Relações Sociais e Trabalhistas. Vol. 4, N. 3, Brasília: Centro Universitário do Distrito Federal-UDF, set.-dez. 2018, p. 26-35.

ALVES, Amauri Cesar; CASTRO, Thiago Henrique Lopes de. Reforma Trabalhista e Movimentos de Reestruturação, Precarização e Redução do Direito do Trabalho no Brasil. In Revista Direito das Relações Sociais e Trabalhistas. Vol. 4, N. 3, Brasília: Centro Universitário do Distrito Federal-UDF, set.-dez. 2018, p. 64-76.

ANTUNES, Ricardo. Os Sentidos do Trabalho: ensaio sobre a afirmação e a negação do trabalho. São Paulo: Boitempo, 2009.

ARANTES, Delaíde Alves Miranda; LEMOS, Maria Cecília de Almeida Monteiro. Em Defesa da Justiça do Trabalho, do Direito do Trabalho e da CLT: os ataques e as ameaças da reforma trabalhista. Revista do Tribunal Superior do Trabalho, v. 83, n. 1, p. 99-100, jan./mar. 2017.

ARNHEIM, Rudolf. Arte y percepción visual. Buenos Aires: Eudeba, 1962.

ARRETCHE, Marta T. S. Emergência e Desenvolvimento do Welfare State: teorias explicativas. In DELGADO, Mauricio Godinho; PORTO, Lorena Vasconcelos (Org.) Welfare State: os grandes desafios do Estado de Bem-Estar Social. São Paulo: LTr, 2019, p. 50-105.

BIAVASCHI, Magda Barros. A reforma trabalhista no Brasil em tempos de acirramento das desigualdades sociais à ação de um capitalismo "sem peias" In: MELO, Raimundo Simão de; ROCHA, Cláudio Jannotti da (Coords.). Constitucionalismo, Trabalho, Seguridade Social e as Reformas Trabalhista e Previdenciária. São Paulo/Brasília: LTr/FAPDF, 2017.

BRIGGS, Asa. The Welfare State in Historical Perspective. In PIERSON, Christopher; CASTLES, Francis G. The Welfare State Reader. Second Edition. Cambridge/UK-Malden/USA: 2006, p. 16-29. 
CASSAR, Vólia Bomfim. CLT Comparada e Atualizada: com a reforma trabalhista. São Paulo: Método, 2017.

CASSAR, Vólia Bomfim; BORGES, Leonardo Dias. Comentários à Reforma Trabalhista - Lei n. 13.467, de 13 de julho de 2017. Rio de Janeiro: Forense/São Paulo: Método, 2017.

CONDÉ, Eduardo A. Salomão. Laços na Diversidade: a Europa social e o Welfare em movimento (1992-2003). Juiz de Fora: UFJF. 2008.

CORREIA, Henrique; MIESSA, Élisson. Manual da Reforma Trabalhista - Lei $n$. 13.467/2017 - o que mudou? Salvador: JusPODIVM, 2018.

DELGADO, Gabriela Neves. Direito Fundamental ao Trabalho Digno. São Paulo: LTr, 2006.

DELGADO, Lucilia de Almeida Neves. Cidadania, Democracia e Direitos Sociais: Impasses e Desafios em um Século de História no Brasil. Revista Direito das Relações Sociais e Trabalhistas - periódico científico do Curso de Direito do Centro Universitário do Distrito Federal - UDF, Brasília: UDF/LTr, Vol. 2, N. 2, Julho/Dezembro 2016, p. 61-73 (versão impressa do periódico digital).

DELGADO, Mauricio Godinho. Constituição da República, Estado Democrático de Direito e Direito do Trabalho. In DELGADO, Mauricio Godinho; DELGADO, Gabriela Neves. Constituição da República e Direitos Fundamentais - dignidade da pessoa humana, justiça social e direito do trabalho. 4. ed. São Paulo: LTr, 2017, p. 33-58. ed., 2018).

Curso de Direito do Trabalho. 16. ed. São Paulo: LTr., 2017 (idem, 17.

. Direito Coletivo do Trabalho. 7. ed. São Paulo: LTr, 2017.

. Direito do trabalho e modernização jurídica. Brasília: Consulex, 1992.

- Princípios Constitucionais do Trabalho e Princípios de Direito Individual e Coletivo do Trabalho. 5. ed. São Paulo: LTr, 2017.

Sindicalismo e Sindicato no Brasil: da democratização promovida pela Constituição da República à Crise e Desinstitucionalização emergentes. Revista Magister de Direito do Trabalho. Porto Alegre: Lex Magister, 2019 (no prelo).

; DELGADO, Gabriela Neves. A CLT aos 65 Anos: Avaliação Jurídica e Sócio-Cultural. Revista Magister de Direito Trabalhista e Previdenciário. Ano V, Número 27. Porto Alegre: Magister, 2008. 
Constituição da República e Direitos Fundamentais dignidade da pessoa humana, justiça social e direito do trabalho. 4. ed. São Paulo: LTr, 2017.

Estruturação e Desenvolvimento da Justiça do Trabalho no Brasil. In DELGADO, M. G.; DELGADO, G. N. Constituição da República e Direitos Fundamentais - dignidade da pessoa humana, justiça social e Direito do Trabalho. 4. ed. São Paulo: LTr, 2017.

A Reforma Trabalhista no Brasil: com os comentários à Lei $\mathrm{n}$. 13.467-2017. São Paulo: LTr, 2017.

Tratado Jurisprudencial de Direito Constitucional do Trabalho. São Paulo: Editora Revista dos Tribunais, 2013.

; PORTO, Lorena Vasconcelos. O Estado de Bem-Estar Social (Welfare State) no Capitalismo Contemporâneo. In DELGADO, Mauricio Godinho; PORTO, Lorena Vasconcelos (Org). Welfare State - os grandes desafios do Estado de BemEstar Social. São Paulo: LTr, 2019, p. 23-49.

DIAS, Carlos Eduardo Oliveira; et. al. Comentários à Lei da Reforma Trabalhista dogmática, visão crítica e interpretação constitucional. São Paulo: LTr, 2018.

DOSSIE REFORMA TRABALHISTA. GT Reforma Trabalhista. Campinas: CESIT/IE/UNICAMP, 2017.

ESTEVES, Juliana Teixeira; et. al. Reforma Trabalhista: a Subordinação das Relações de Trabalho na Dinâmica do Mercado. In Revista Direito das Relações Sociais e Trabalhistas. Vol. 4, N. 2, Brasília: Centro Universitário do Distrito Federal-UDF, mai.-ago. 2018, p. 87-92.

FARIA, Carlos Aurélio Pimenta de. Uma genealogia das teorias e tipologias do Estado de Bem-Estar Social. In DELGADO, Mauricio Godinho; PORTO, Lorena Vasconcelos (Org). O Estado de Bem-Estar Social no Século XXI. $2^{\underline{a}}$ ed. São Paulo: LTr, 2018. p. 33-78.

FAUSTO, Bóris. Trabalho Urbano e Conflito Social (1890-1920). São Paulo: Difel, 1976.

FELICIANO, Guilherme Guimarães; TREVISO; Marco Aurélio Marsiglia; FONTES, Saulo Tarcísio de Carvalho (Orgs.). Reforma Trabalhista - visão, compreensão e crítica. São Paulo/Brasília: LTr/Anamatra, 2017.

; CONFORTI, Lucina Paula; PORTO, Noemia. A reforma trabalhista e suas "modernidades": o Brasil na 106" Conferência Internacional do Trabalho e as violações às normas do trabalho. Disponível em: <https://jota.info>. Acesso em: 21 jul. 2017. 
GARCIA, Gustavo Filipe Barbosa. Reforma Trabalhista - análise crítica da Lei $\mathrm{n}$. 13.467/2017. 2. ed. Salvador: JusPodivm, 2017.

GUNTHER, Luiz Eduardo; ALVARENGA, Rúbia Zanotelli de (Coord.); SCHIO, Adriana Cavalcante de Souza (Org.). Reforma Trabalhista - impacto e aplicação da Lei n. 13.467, de 2017. São Paulo: LTr, 2018.

HORTA, Denise Alves; FABIANO, Isabela Márcia de Alcântara; KOURY, Luiz Ronan Neves; OLIVEIRA, Sebastião Geraldo de. Direito do Trabalho e Processo do Trabalho — reforma trabalhista, principais alterações. São Paulo: LTr, 2018.

KERSTENETZKY, Celia Lessa. O Estado de Bem-Estar Social na Idade da Razão - a reinvenção do Estado Social no mundo contemporâneo. Rio de Janeiro: Elsevier, 2012.

KREIN, José Dari; GIMENEZ, Denis Maracci; SANTOS, Anselmo Luís dos. Dimensões Críticas da Reforma Trabalhista no Brasil. Campinas: Curt Nimuendajú/CESIT, 2018.

LIMA, Francisco Meton Marques de; LIMA, Francisco Péricles Rodrigues Marques de. Reforma Trabalhista - entenda ponto por ponto. São Paulo: LTr, 2017.

MELO, Raimundo Simão de; ROCHA, Cláudio Jannotti da (Coords.). Constitucionalismo, Trabalho, Seguridade Social e as Reformas Trabalhista e Previdenciária. São Paulo/Brasília: LTr/FAPDF, 2017.

MIESSA, Élisson; CORREIA, Henrique; MIZIARA, Raphael; LENZA, Breno. CLT Comparada com a Reforma Trabalhista. Salvador: JusPodivm, 2017.

O Novo Código de Processo Civil e Seus Reflexos no Processo do Trabalho. Salvador: JusPodivm, 2015.

MINISTÉRIO PÚBLICO DO TRABALHO. Nota Técnica n. 8, de 26 de junho de 2017, da Secretaria de Relações Institucionais do Ministério Público do Trabalho (MPT), subscrita pelo Dr. Ronaldo Curado Fleury, Procurador Geral do Trabalho.

Temas da Lei n¹3.467/2017 ("Reforma Trabalhista") à luz das normas internacionais. Manual de Apoio à atuação dos Membros do Ministério Público do Trabalho. Brasília: Ministério Público do Trabalho, 2018.

MORAES FILHO, Evaristo de. Tratado Elementar de Direito do Trabalho. Vo. I. Rio de Janeiro: Freitas Bastos, 1960.

NAHAS, Thereza; PEREIRA, Leone; MIZIARA, Raphael. CLT Comparada Urgente - breves comentários, regras \& aplicação e mapas conceituais dos artigos reformados. São Paulo: Thomson Reuters/Revista dos Tribunais, 2017.

OLIVEIRA, Aristeu de. Reforma Trabalhista - CLT e Legislação Comparadas - Lei n. 13.467/2017. 2. ed. GEN/Atlas, 2018. 
OLIVEIRA, Francisco Antonio de. Comentários à Lei n. 13.467, de 13 de julho de 2017. São Paulo: LTr, 2017.

PIRES, Rosemary de Oliveira; LORENTZ, Lutiana Nacur; BARBOSA, Arnaldo Afonso (Coord.). A Reforma Trabalhista (Lei n. 13.467/2017) na Visão dos Magistrados do Trabalho, Procuradores do Trabalho e Advogados Trabalhistas. Belo Horizonte: RTM, 2019.

PIRES, Rosemary de Oliveira (Org.). Reforma Trabalhista - quadro comparativo da CLT e legislação ordinária afetadas pela Lei n. 13.467/2017. Belo Horizonte: RTM, 2017.

PRETTI, Gleibe. Comentários à Lei sobre a Reforma Trabalhista - o que mudou na CLT e nas relações de trabalho. São Paulo: LTr, 2017.

ROCHA, Cláudio Jannotti da. A Dispensa Coletiva da Reforma Trabalhista Analisada à Luz do Direito Constitucional e da Teoria dos Precedentes Judiciais. In: MELO, Raimundo Simão de; ROCHA, Cláudio Jannotti da (Coord.). Constitucionalismo, Trabalho, Seguridade Social e as Reformas Trabalhista e Previdenciária. São Paulo/Brasília: LTr/FAPDF, 2017.

SCALÉRCIO, Marcos; MINTO, Tulio Martinez. CLT Comparada - conforme a reforma trabalhista. São Paulo: LTr, 2017.

SCHIAVI, Mauro. A Reforma Trabalhista e o Processo do Trabalho. São Paulo: LTr, 2017.

SEVERO, Valdete Souto; MAIOR, Jorge Luiz Souto. Manual da Reforma Trabalhista - pontos e contrapontos. São Paulo: Sensus/AATSP, 2017.

SILVA, Homero Batista Mateus da. Comentários à Reforma Trabalhista - análise da Lei n. 13.467/2017 - artigo por artigo. São Paulo: Thomson Reuters/Revista dos Tribunais, 2017.

SINHA, Chris; BERNÁRDEZ, Enrique. Espaço, tempo e espaço-tempo: metáforas, mapas e fusões. Tradução de Wany Bernardete de Araújo Sampaio. Revista Brasileira de Linguística Antropológica. Volume 7, Número 1, Julho de 2015.

SOUZA JÚNIOR, Antonio Humberto; SOUZA, Fabiano Coelho de; MARANHÃO, Ney; AZEVEDO NETO, Platon Teixeira de. Reforma Trabalhista - análise comparativa e crítica da Lei n. 13.467/2017. 2. ed. São Paulo: Rideel, 2018.

SUPIOT, Alain. O Espírito de Filadélfia: a justiça social diante do mercado total. São Paulo: Sulina, 2015.

TEIXEIRA FILHO, Manoel Antonio. O Processo do Trabalho e a Reforma Trabalhista - as alterações introduzidas no Processo do Trabalho pela Lei $n$. 13.467/2017. São Paulo: LTr, 2017. 
TEIXEIRA, Marilane Oliveira; et. al. Contribuição Crítica à Reforma Trabalhista. Campinas: Instituto de Economia/CESIT, 2017

TEPEDINO, Gustavo; MELLO FILHO, Luiz Philippe Vieira de; FRAZÃO, Ana; DELGADO, Gabriela Neves (Coordenadores). Diálogos entre o Direito do Trabalho e o Direito Civil. Editora Revista dos Tribunais: São Paulo: 2013.

TITMUSS, Richard. Universalism versus Selection. In PIERSON, Christopher; CASTLES, Francis G. The Welfare State Reader. Second Edition. Cambridge/UKMalden/USA: 2006, p. 41-47.

VEIGA, Mauricio de Figueiredo Corrêa da. Reforma Trabalhista e os Seus Impactos - com as alterações promovidas pela Medida Provisória n. 808/2017. São Paulo: LTr, 2017.

VIANNA, Luiz Werneck. Liberalismo e Sindicato no Brasil. Rio de Janeiro: Paz e Terra, 1989. 